\title{
ULAŞIM SİSTEMLERİ VE UŞAK
}

Transportation Systems and Uşak

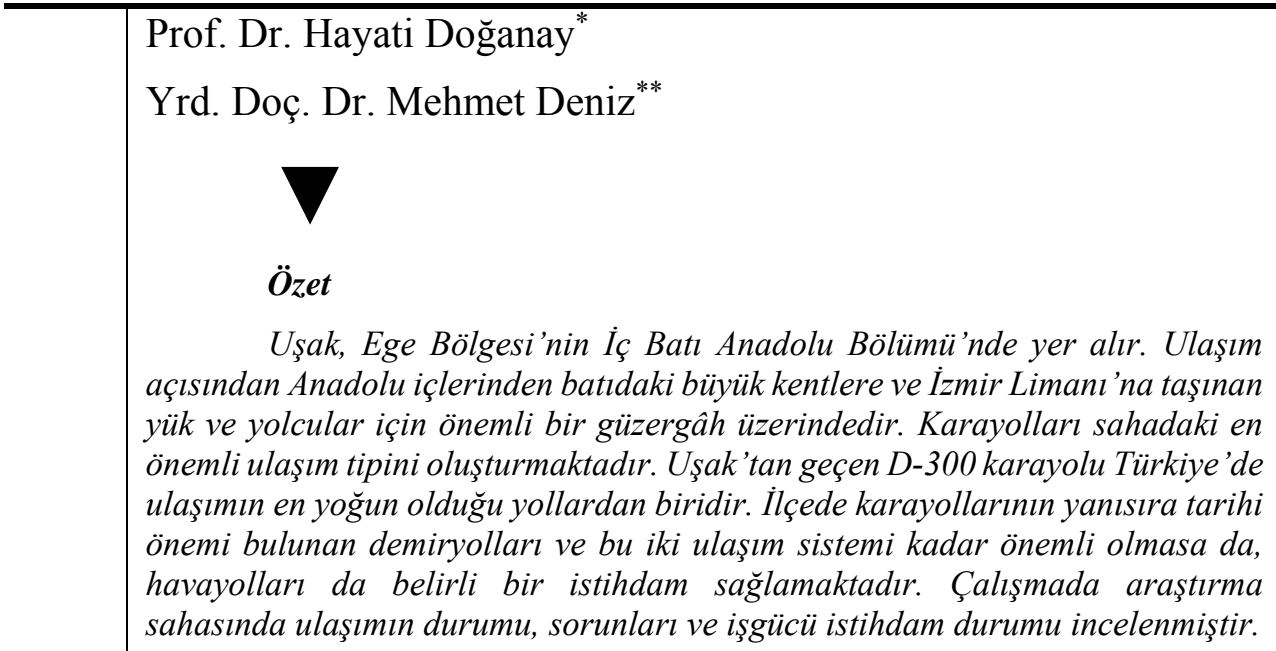

Anahtar Sözcükler: Ulaşım, Uşak, Ulaşım Coğrafyası

\section{Absract}

Uşak is situated in Inner Western Anatolia Subregion. In terms of transportation, it is on a important route, to the big cities in the west and for the goods and passengers that transportted to İzmir harbour. Highways represent the most important type of transportation in the research area. D-300 highway that possess from Uşak, one of the most intense way in Turkey. As well as the highways in the district, historical railway and the airlines which is not important as these two transportation types, provide a specific employment. In this study, the state of transportation, problems and employment have been examined.
\end{abstract}

Key Words: Transportation, Uşak, Transportation Geography

* Atatürk Üniversitesi, Kâzım Karabekir Eğitim Fakültesi Coğrafya Eğitimi Anabilim Dalı, hdoganay@atauni.edu.tr.

** Uşak Üniversitesi, Fen-Edebiyat Fakültesi Coğrafya Bölümü, mehmet.deniz@usak.edu.tr 
Ulaşım Sistemleri ve Uşak

\section{Giriş}

Ulaşım karayolu, demiryolu, denizyolu ve havayolları ile insan ya da onun ürettiklerinin bölge, ülke ve kıtalar arasında yer değiştirmesidir (Tümertekin ve Özgüç, 2007; Taşlıgil, 2010). Bu yer değiştirme ve taşınma sırasında sürdürülen hizmetler bir üretim şekli olarak karşımıza çıkmaktadır (Tümertekin, 1987). Ayrıca ulaşım sistemleri peyzaj üzerinde önemli değişikliklere sebep olmaktadırlar. Bu nedenle ulaşım, coğrafya araştırmalarında ayrı bir önemi olan ekonomik bir etkinlik olmasının yanında, kentlerde kapladığı alan ve istihdam ettiği nüfus bakımından önemli bir şehirsel fonksiyona ve fonksiyon alanlarına sahiptir. Bazı araştırmacılar bu gibi özellikleri sebebiyle ulaşımı, kalkınma ve küreselleşmenin en önemli etkenleri arasında göstermektedir (Tümertekin ve Özgüç, 2007).

Araştırma sahası olan Uşak ve çevresi, Ege Bölgesi’nin İç Batı Anadolu Bölümü'nde yer almaktadır. Bu bölüm Ege Bölgesi'nin İç Anadolu, Marmara ve Akdeniz Bölgelerine sokulduğu yüksek bir sahayı oluşturur. Uşak ili ve şehri, Gördes-Uşak yöresi olarak adlandırılan az engebeli bir platoda yer almaktadır (Darkot, Tuncel, 1995). Zengin bir bitki örtüsü ve doğal kaynaklara sahip olan Uşak, Murat Dağı'nın güneybatısında yer alır (Arınç, 2006 ). Yaklaşık $55 \mathrm{~km}^{2}$ lik bir alana sahip olan Uşak Ovası (Arınç, 2006) kentin ova yönünde gelişmesinde etkili olmaktadır. İl kuzeyden Kütahya, batıdan Manisa, güneyden Denizli, doğudan ise Afyonkarahisar illeri ile komşudur. İlin merkez ilçesinin, ilin tüm ilçeleri ile sınırı vardır. İlçenin komşuları kuzeyde Şaphane ve Gediz, kuzeybatıda ve batıda Selendi, batıda Kula, güneyde Eşme, Ulubey ve Karahallı, güneydoğuda Sivaslı ve doğuda Banaz ilçeleridir (Şekil 1).

Coğrafi koşullar itibari ile tarihi bir yol üstü yerleşmesi (Özdeğer, 2001) olan Uşak kentinin gelişiminde etkili olan etmenlerden birinin de, önemli tarihi ticaret yollarından olan Kral Yolu olduğu farklı çalışmalarda belirtilmektedir (Bilgen, 1999). Uşak çevresi İlk Çağ boyunca ve Orta Çağ başlarında küçük bir yerleşme merkezi iken Yeniçağ başlarında gelişmeye başlamıştır. Gelişimini büyük ölçüde ulaşıma borçlu olan kentin, bugünkü uzun ekseni olan doğu-batı yönlü uzanışında, tarihi ipek yolunun da etkisi ile oluşmuştur (Yalçınlar, 2001).

Baykara, bugünkü Uşak kentinin, muhtemelen XII. yy’ın sonlarında Türkler tarafından kurulduğunu belirtmektedir (Baykara, 1978'den aktaran: Tutsak, 1994). Ancak, kurulduğundan beri farklı devletlerin sınırları içerisinde kalmıştır.

Tarihi kentlere bakıldığında, özellikle Orta Çağ ve Roma kentlerinde merkeziyet özelliği bulunan kentlerin, ulaşım ağlarının kesiştiği konumlarda kurulduğu dikkat çekmekte (Gottman, 1976); hatta bazı yerleşmelerin yolları denetim altına tutabilecekleri yerlere özellikle kurulduğu görülmektedir (Yazıcı, 1995). Bu avantajın gelişiminini teşvik ettiği ticaret ve diğer ekonomik faaliyetler, kentlerin büyümesinde etkili olmuştur. Aynı zamanda önemli yollar üzerinde bulunan yerleşmeler yolcular için uğrak yeri olma niteliği de kazanmaktadırlar. Örneğin Anadolu'nun değişik yörelerinde görüldüğü üzere kervansaraylar ve hanlar, ulaşım güzergâhlarına kurularak bunun önemini göstermektedir. $\mathrm{Bu}$ bakımdan Uşak şehrinin kurulduğu kesimde bugün bir kısmı harabe haline gelmiş, bir kısmı ise hâlâ ayakta duran hanlarla rastlamak mümkündür. Bu tip yapılar özellikle tarihi dokunun 
korunduğu ve kentin ilk kuruluş yerlerinden olan Köme, İslice, Özdemir, Kurtuluş Mahalleleri ve çevresinde karşımıza çıkmaktadır.

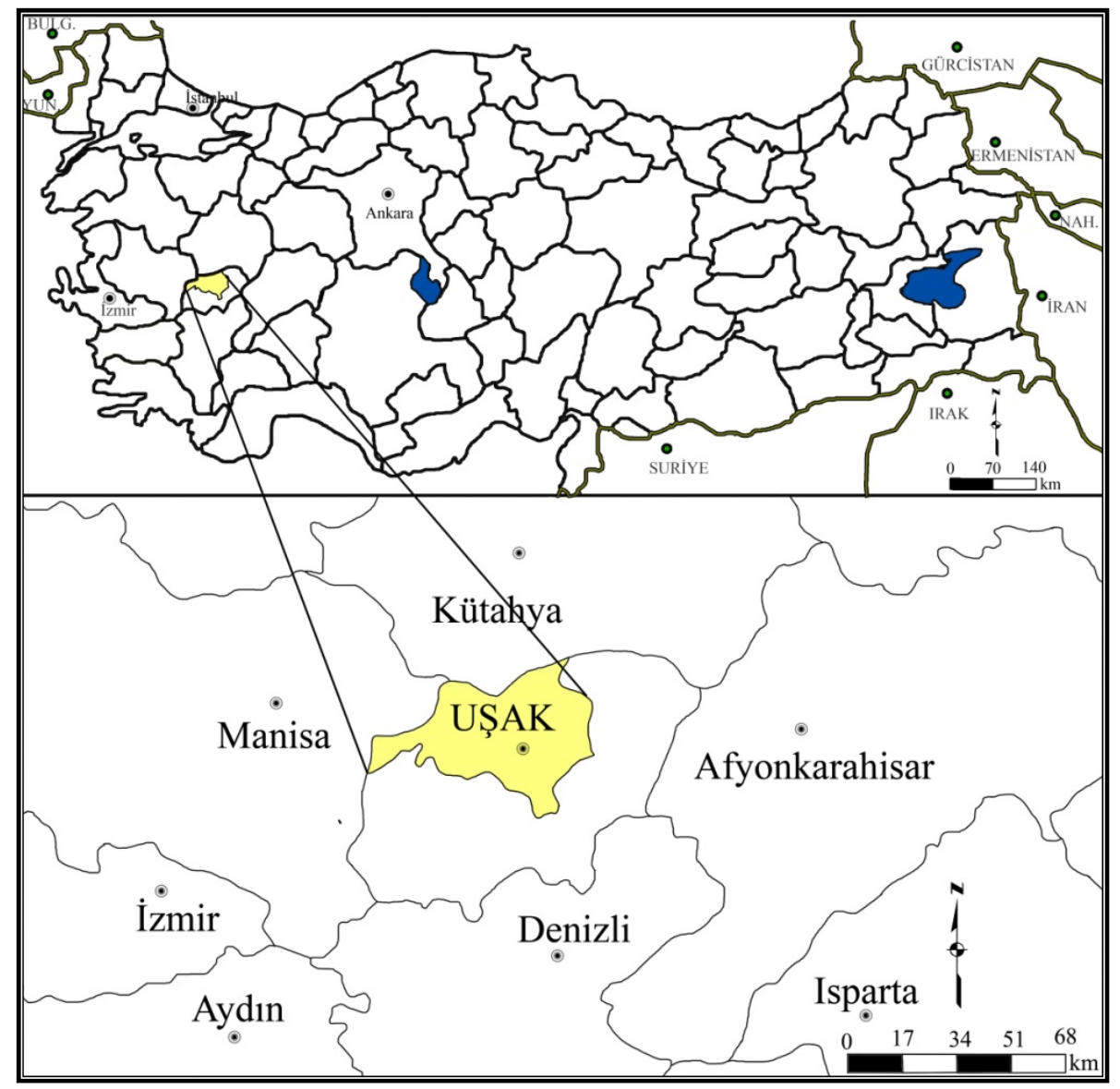

Şekil 1. Araştırma Sahasının Lokasyon Haritası

Geçmişte şehirlerarası ulaşım yollarının bu güzergâhtan geçmesi, hanların buralarda yapılmasının en önemli nedenidir. Bugün otel olarak kullanılan Dülgeroğlu Oteli de bu tip bir hanın restore edilmesi ile yapılmıștır. Günümüzde banka olarak kullanılan eski Çukur Han-Taş Han, yeri kaybolmuş olan Lonca Hanı da eski önemli hanlarındandır. Gediz ve Uşak şehirleri arasında da Sicim Hanı kervansaray olarak kervan ve yolculara hizmet vermişti. Şehirde 1970'lere kadar hizmet vermiş olan hanlar; Hacı Gedik Hanı, Paşa Hanı, Deve Hanı, Halitoğlu Hanı, Pekmez Hanı, Yılancı Hanı, Müftü Hanı'dır. Aynı dönemde bu hanlar dışında parası olmayanların konaklayabilmesi için yapılan iki de Vakıf Hanı bulunmaktadır (Tümer, 1971). 


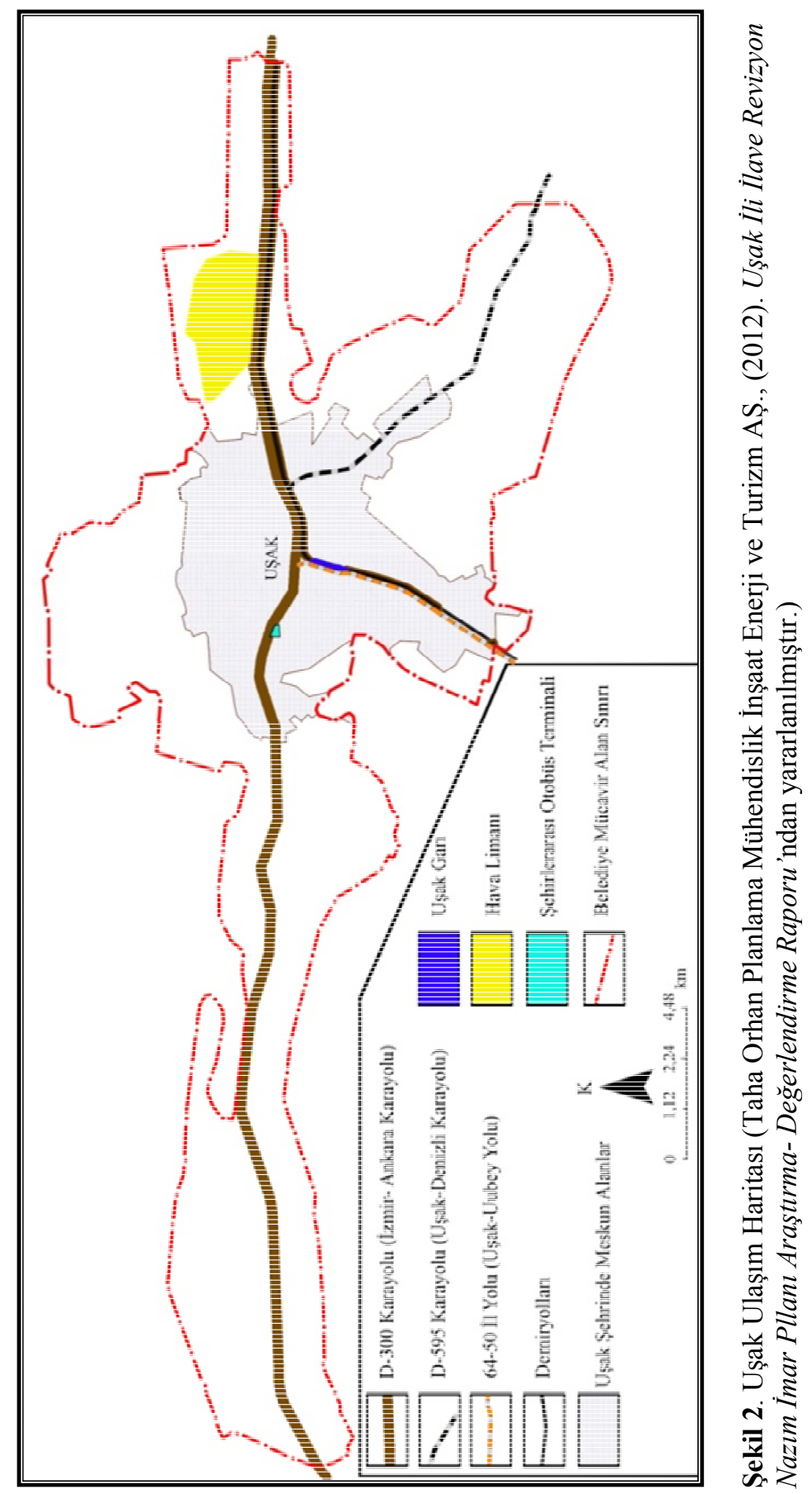

4 - Doğu Coğrafya Dergisi - 32 
Nurdağı ve Pozantı'da görüldüğü gibi ulaşım bazı yerleşmelerin kurulması ya da gelişmesinde etkili olduğu gibi, oranın günümüzdeki en önemli fonksiyonu da olabilir (Doğanay ve Koca, 1998; Tıraş, 2002 ). Kimi yerleşmeler ise ulaşım hatlarına bağlı olarak kurulurken, zamanla bu fonksiyon önemini kaybedebilmektedir (Başıüyük, 2006). Zira büyüyen kent alanı ve artan nüfusa bağlı olarak farklı sosyo-ekonomik faaliyetler kentte gelişmeye başlamaktadır. Farklı çalışmalarda ekonomik fonksiyonları açısından sanayi şehri olarak kabul edilen (Çetin, 2001) araştırma sahası Uşak’ta da ulaşımın kentin büyüyüp gelişmesinde en önemli işlevlerden biri olduğuna daha önce değinilmişti. Ticaret yolları üzerindeki yerleşmenin gelişimi ulaşım hatlarına uymuş, demiryollarının döşenmesi ve gar binalarının yapılması ile şehir zamanla bu yöne kaymıştır. Bugün de kentin gelişimi D-300 ve D-595 nolu karayollarına paralel şekildedir. Ayrıca yeni yapılan çevre yollarının ve hızlı tren hattının yerleşme nüvelerini kendine çekme ihtimali de muhtemeldir.

Ulaşıma uygun coğrafi konumlar, yerleşmelerin kurulması ve gelişmesi bakımından (Özdemir, 2008), özellikle ulaşım yollarının kavşağındaki kentler ticaret ve sanayi bakımından (Göney, 1977) avantajlara sahiptir. Uşak'ta kara ve demiryolları açısından önemli bir yol üstü yerleşmesidir. Çalışmada araştırma sahası ile ilgili geçmiş çalışmalardan (Bilgen, 1999; Yayla, 2001) da yararlanılarak ulaşımın araştırma sahasındaki durumu, sorunları, bu sektördeki istihdam incelenmeye çalışılmıştır. Ulaşım ve ulaştırma günümüzde bilgi, sermaye, iletişim gibi hizmetlerin erişimini de içermektedir (Şahin, 2013). Ancak çalışma sadece karayolu, demiryolu ve havayollarını kapsamaktadır.

\section{Karayolları}

Türkiye'nin orografik yapısı, kara ve demir yollarının dağılışı ve uzanışı gibi özelliklerini etkileyerek doğu-batı yönlü gelişmesini sağlamıştır (Doğanay, 2011). Ayrıca, yolların geçmiş tarihi yollar ile az çok paralellik gösterdiği dikkat çekmektedir. (Gürsoy, 1974). Mekânlar arası iletişimi sağlayan ulaşım sistemlerinin en eskisi, geçmişi İlk Çağa kadar uzanan karayollarıdır (Ertin, 1993). Cumhuriyet döneminde Türkiye'de ulaşımın geçmişteki durumuna bakıldığında devlet eliyle öncelikle demiryollarının geliştiği, zamanla demiryolları ihtiyaçlara cevap verememesi ve diğer sebeplerle 1940'lı ve 1950'li yıllardan itibaren karayollarının da gelişim gösterdiği (Şahin, 2013; Avc1, 2005; Şahin, 2006) dikkat çekmektedir. Uşak'ın, tarihi çok eskilere uzanan ticaret yolları üzerinde olması sebebiyle karayolu taşımacılığı yerleşmenin kuruluşundan günümüze kadar en önemli ulaşım sistemi olmuştur. Ancak Uşak ilinin modern ilk asfalt karayolu, 1966 yılında hizmete giren İzmirAfyon karayoludur (Bilgen, 1999).

Uşak kenti yerleşim alanı ve il genelinde, karayolu açısından en önemli yol, İzmirAnkara yolu olarak da bilinen D-300 karayoludur. Ulusal numaralandırma sistemine göre D300 nolu yola, Avrupa ana karayolları numaralandırma sistemine göre E-96 adı verilmiş̧ir. Yol uluslararası E-Yollar (European Roads) sisteminde Batı-Doğu yönlü ara-orta yollar sinıfına girmektedir (İnternet 1). E 96 karayolu İzmir-Ankara yolunun İzmir ve Sivrihisar arasındaki $440 \mathrm{~km}$ uzunluğundaki kısmını kapsamaktadır (İnternet 2). D-300 karayolunun bütünü ise 2004 km olup, İzmir-Çeşme'den başlayıp Van-Kapıköy sınır kapısına kadar devam etmektedir (İnternet 3). 
Ulaşım Sistemleri ve Uşak

Uşak ilinde, şehirlerarası karayolu ulaşımı açısından önemli olan farklı bir güzergah da kent yerleşim alanından güneydoğuya yönelen D-595 karayoludur. D-300 kadar yoğun bir araç trafiğine sahip olmasa da, bu yol da yük ve yolcu taşımacılığı açısından önemli bir güzergahtır. Çünkü Uşak ve çevresinden Denizli’ye olan karayolu bağlantısı bu yol vasıtası ile yapılmaktadır ${ }^{1}$. $500 \mathrm{~km}$ uzunluğundaki bu yol Kocaeli’nin Karamürsel ilçesinden başlayıp, Denizli’nin Kaklık ilçesinde son bulmaktadır (İnternet 4). Şehir merkezinde D-300 karayolundan ayrılan yol Uşak Karma Organize Sanayi Bölgesinden geçmekte, Sivaslı, Çivril gibi ilçe merkezlerinden geçtikten sonra Baklan ve Çal ilçesi sınırlarına girmekte nihayet Kaklık ilçesinde D-320 karayoluna bağlanmaktadır.

$\mathrm{Bu}$ iki yol kadar işlek olmasa da şehir yerleşim sahasından çevre yerleşmelere olan diğer bir önemli güzergâh da Uşak-Ulubey (64-50 nolu il yolu) yoludur. Bu yol Ulubey ve Eşme ilçelerine olan ulaşımda kullanılan en önemli güzergâhtır. Ayrıca Denizli’nin Güney, Buldan, Sarayköy ilçeleri ve Manisa'nın Alaşehir ilçelerine gidenler de bu yolu kullanmaktadır. Bu yol vasıtası ile D-595 yolu ile de gidilebilen Bekilli ve Çal ilçelerine de ulaşılabilmektedir. Ancak bu ilçelerin ve yol güzergâhındaki yerleşmelerin küçük yerleşmeler olması ve Denizli ya da Aydın istikametindeki büyük yerleşmelere alternatif yolların olması sebebiyle bu yol diğer yollar kadar gelişmemiştir. Yolun durumu, bakım şartları ve geçen araç sayısı da buna gösterge olabilmektedir.

Araştırma sahasında ulaşımın önemini ortaya koymak amacıyla farklı çalışmalarda olduğu gibi (Doğanay, 1983; Koca, 1994; Şahin, 2000; Bekdemir, 2004; Çetin, 2007; Arıbaş, 2008; Yürüdür, 2009; Altaş, 2009), bölgedeki trafik yoğunluğuna bakılabilir. Karayolu ulaşımı açısından Uşak şehrinin bir yoğunluk merkezi olduğu Karayolları Genel Müdürlüğü tarafından yapılan sayımlar ve tahminlerle de görülmektedir. Çünkü D-300 karayolunda Uşak şehrinden çıktıktan sonra Güre ve Uşak arasında günde 11811 motorlu araç, Uşak ve Banaz arasında 11028 motorlu araç, Uşak-Sivaslı arasında 3244 motorlu araç, Uşak-Ulubey arasında 2213 motorlu araç geçtiği görülmektedir. Bu sayıların Uşak kent merkezinde artması ve 23895 motorlu araca ulaşması da bunun göstergesidir (Tablo 1). Yine aynı tablodan anlaşılacağı üzere çevresine göre daha önemli bir üretim merkezi olan Uşak şehrinin doğusundaki sayım noktaları ile batısındaki sayım noktaları arasında fark bulunmaktadır. Hemen hemen tüm araç türlerinde sayının batıya doğru artmasındaki en önemli sebep batıda İzmir gibi önemli bir merkezin yer almasıdır. Zira İzmir; hastaneleri, ticari potansiyeli ve limanı ile Uşak’ı kentsel etki bölgesi içine almaktadır. Bölgede üretilen tarım ürünleri ve seramik gibi ürünlerin limana naklinde, ve yolcu taşımacılığı ile bu güzergâhta birçok araç trafiğe katılmaktadır.

${ }^{1}$ Farklı daha kısa olan tali yollar ile ulaşılabilse de Aydın yönüne giden araçlar da bu güzergâhı kullanabilmektedir. 
Tablo 1. Uşak ve yakın çevresindeki karayolu ulaşım akslarında yıllık ortalama motorlu araç trafiği, (2012)*

\begin{tabular}{|c|c|c|c|c|c|c|c|c|c|c|c|c|}
\hline \multirow{3}{*}{\begin{tabular}{||l|} 
Araç Tipi \\
\\
Otomobil \\
\end{tabular}} & \multicolumn{12}{|c|}{ Araç Sayıs1 ve Oranı(\%) } \\
\hline & \multicolumn{2}{|c|}{$\begin{array}{l}\text { Uşak Şehir } \\
\text { Merkezi }\end{array}$} & \multicolumn{2}{|c|}{$\begin{array}{l}\text { Uşak-Banaz } \\
\text { Arası }\end{array}$} & \multicolumn{2}{|c|}{$\begin{array}{c}\text { Uşak-Sivaslı } \\
\text { Arası }\end{array}$} & \multicolumn{2}{|c|}{$\begin{array}{c}\text { Uşak-Güre } \\
\text { Aras1 }\end{array}$} & \multicolumn{2}{|c|}{$\begin{array}{c}\text { Sivasl1-Çivril } \\
\text { Arası }\end{array}$} & \multicolumn{2}{|c|}{$\begin{array}{c}\text { Uşak-Ulubey } \\
\text { Aras1 }\end{array}$} \\
\hline & 16744 & $\% 70,1$ & 7083 & $\% 64,2$ & 2072 & $\% 63,9$ & 7297 & $\% 61,8$ & 1741 & $\% 67,7$ & 1670 & $\% 75,5$ \\
\hline Orta yüklü ticari taşıt & 1913 & $\% 8,0$ & 768 & $\% 7,0$ & 300 & $\% 9,2$ & 933 & $\% 7,9$ & 239 & $\% 9,3$ & 234 & $\% 10,6$ \\
\hline Otobüs & 492 & $\% 2,1$ & 432 & $\% 3,9$ & 43 & $\% 1,3$ & 524 & $\% 4,4$ & 33 & $\% 1,3$ & 5 & $\% 0,2$ \\
\hline Kamyon & 2748 & $\% 11,5$ & 1403 & $\% 12,7$ & 558 & $\% 17,2$ & 1722 & $\% 14,6$ & 424 & $\% 16,5$ & 228 & $\% 10,3$ \\
\hline $\begin{array}{l}\text { Kamyon-römork- } \\
\text { çekici-yarı romörk }\end{array}$ & 1998 & $\% 8,4$ & 1342 & $\% 12,2$ & 271 & $\% 8,4$ & 1335 & $\% 11,3$ & 135 & $\% 5,2$ & 76 & $\% 3,4$ \\
\hline Toplam & 23895 & $\% 100$ & 11028 & $\% 100$ & 3244 & $\% 100$ & 11811 & $\% 100$ & 2572 & $\% 100$ & 2213 & $\% 100$ \\
\hline
\end{tabular}

Kaynak: Karayolları Genel Müdürlüğü Trafik Güvenliği Dairesi Başkanlığı verilerinden Bkz. www.kgm.gov.tr (24.02.2014)

Tablo 1'e bakıldığında Uşak kenti yerleşim alanını kullanan motorlu araçların büyük çoğunluğunun $(16744 ; \% 70.1)$ otomobil olduğu görülmektedir. Gerek otomobil gerekse toplam araç sayısı bakımından D-300 karayolunun önemi buradan da anlaşılmaktadır. Çünkü bu yolu kullanan araç sayısının Sivaslı ve Ulubey yollarını kullanan araç sayısına göre oldukça yüksek olduğu dikkat çekmektedir.

Karayolu ulaşımı açısından Uşak şehrine ulaşmada önemli bir sorun yaşanmaz iken farklı sebeplerden ötürü karayolu ulaşımında eksikliklerin olduğu söylenebilir. Bu hususta değinilmesi gereken bir konu da Uşak Otogarı'dır. Birçok yerleşmede olduğu gibi Uşak'ta da şehirlerarası karayolu ulaşımında en önemli tesis terminaldir. Uşak Otogarı 1992 yılında yapılmış ve 1995 'te faaliyete geçmiştir. Garajda ulaşım acenteleri dışında 4 farklı dükkân (Büfe vb.) yer almaktadır. Kentin ve garajın doğu-batı yönlü İzmir-Ankara yolu üzerinde bulunması sebebiyle birçok aracın transit geçiş güzergâhı üzerinde bulunmaktadır ve genellikle kalkış ve varış noktası olmaktan ziyade ara bir durak olmasından dolayı karayolları açısından kente ulaşım sıkıntısı bulunmamaktadır. Bazı araçların garaja uğramaması nedeniyle kente uğrayan şehirlerarası yolcu taşımacılığı yapan araçların kesin olmamakla birlikte garaja giriş sayısı günde 500 aracın üstündedir ${ }^{2}$.

Uşak terminalinde yer alan acentelerde yaklaşık 99 firma yolcu taşımacıllı̆g 1 yapmaktadır. Bu firmalara ait araçlar dışında yakın ilçelere kalkan yaklaşık 171 araç bulunmaktadır. $\mathrm{Bu}$ araçlar günde 217 sefer yapmaktadır. Otogarda acenteler dışında 4 dükkânda 9 personel çalışmaktadır. Bu 9 kişi haricinde garajda ulaşım hizmetlerinde yaklaşık 90 kişi istihdam edilmektedir. Uşak garajından kalkan araçların büyük çoğunluğu İzmir

* Sivaslı-Çivril, Uşak-Ulubey, Uşak-Banaz arasındaki veriler taşınabilir taşıt sayım ve sınıflandırma istasyonları ile ölçülmüş, diğerlerinde ise KGM'ne göre tahmini değerler verilmiştir.

${ }^{2}$ Garaj idaresinden alınan verilere göre kesin bir rakam vermek zor olmakla beraber tüm araçlar cinsinden 07-09-2013 tarihinde 584 araç; 07,01,2014 tarihinde 632 araç garaja giriş yapmıştır. 
Ulaşım Sistemleri ve Uşak

istikametine gitmektedir. Biletli yolcuların İzmir'den sonra en çok gittikleri istikamet Ankara, Eskişehir, İstanbul ve Konya'dır.

Ulaşım, şehirlerin fizyonomi ve morfolojik gelişiminde rol oynamasının (Aliağaoğlu ve Uğur, 2012) yanında, kentlerin ulaşım tesis ve alanları, görüntüleri ile kentler hakkında fikir vermektedir (Gök, 2000). Bu açıdan bakıldığında Uşak Şehirlerarası Otobüs Terminali'nin şehrin prestiji açısından planlı, şehir ve çevresi için yeterli bir terminal olduğunu söylemek güçtür. Otogar eskimiş ve işlevini yitirmiştir. Deprem dayanıklılığı da bulunmayan tesiste yolcuların beklemesi için yeterli kapalı alan yer almamaktadır. Otobüs peronu olmayan tesiste güvenlik kamerası gibi güvenlik hizmetleri de yetersizdir (Foto 1). Özellikle şehirlerarası ulaşımda önemi her geçen gün artan Uşak'ta yeni ve modern bir tesise duyulan ihtiyaç her geçen gün artmaktadır. Bu nedenle Ankara-İzmir karayolu üzerinde Çarıkköy ve İkisaray köyleri yakınlarında yeni bir garajın yapımına karar verilmiştir.

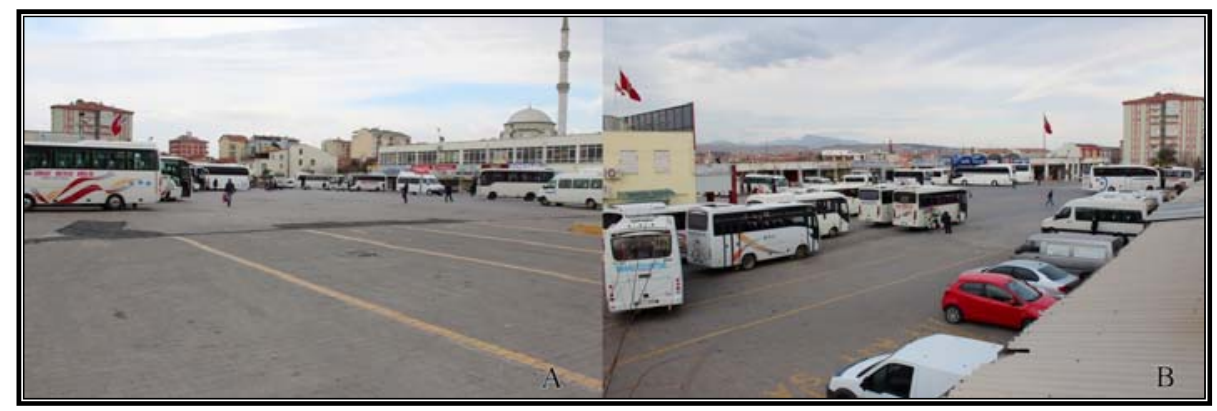

Foto 1. Farklı açılardan Uşak Garajı'nın görünümü

Yukarıda söz konusu edilen yetersizlikler sebebiyle araştırma sahasında ulaşım sektörünün en önemli işvereni olan ve şehirlerarası yolcu taşımacılığında hizmet veren Anadolu Turizm garajın hemen yanında yine garaja ait sahada kendi tesislerini oluşturmuştur. Şehirlerarası ulaşım faaliyetleri şehir nüfusunun yanında şehrin etki bölgesindeki nüfusa da hizmet vermektedir (Kesici,1995). Bu nedenle şehirlerin önemli işlevlerinden birini oluşturmaktadırlar. Bu sektörde gerek şehrin kendi nüfusunun bir kısmı gerekse şehir dışında yaşan belirli bir nüfus istihdam edilmektedir. Firma bünyesinde 270 kaptan, 152 kabin memuru, 22 idari personel, 114 yer personeli, 24 çağrı merkezi görevlisi ve 54 Anadolu Mola dinlenme tesislerinde çalışan personel ile 636 kişiye istihdam sağlanmaktadır. Firma bünyesinde 117 otobüs bulunmaktadır.

Üç personel ve iki yönetici ile idare edilen Uşak Şoförler Odası'ndan aldığımız verilere göre merkez ilçede 197 halk otobüsü 15 taksi durağı, 150 kamyonet faaliyet göstermektedir. İlçede kamyoncular kooperatifinde 400 kadar kamyonla taşımacılık yapılırken 10 kadar da ambar bulunmaktadır. Uşak Şoförler Odası'na kayıtlı 1040 (2014) üye bulunmaktadır. Köy garajından (eski garaj) 200 kadar araç kalkmaktadır. 270-300 kadar da servis aracı bulunmaktadır. 2013 yılında Trafik Tescil ve Denetleme Şube Müdürlüğü kayıtlarına göre ise Uşak merkez ilçede 94 taksi, 436 umum servis aracı, 124 özel halk otobüsü, 104 diğer hizmetler için kayıtlı toplam 758 araç olduğu görülmektedir (Uşak Trafik 
Tescil ve Denetleme Şube Müdürlüğü, 2013). Uşak Ticaret Odası'na kayıtlı 105 üye de ulaştırma ve depolama faaliyetlerini konu alan sektörlerde hizmet vermektedir.

Uşak'ta karayollarının bakım ve onarımına hizmet veren bir diğer kurum, Karayolları 2. Bölge Müdürlüğü'ne bağlı 25. Şube Şefliği'dir. Şefliğin görev sahasına, Manisa ve Denizli'ye ait sahalar da girmektedir. Şubenin hizmet ettiği sahanın Uşak ili sınırları içinde kalan kısmında 173 km devlet, 297 km il, 154,4km’si bölünmüş yol olmak üzere toplam $470 \mathrm{~km}$ yol bulunmaktadır. Uşak ili sınırları içinde Merkez, Banaz ve Eşme'de tesisleri ve bakımevleri bulunan Karayolları 25. Şube Müdürlüğü’nün yine il içinde Çiftlik Köy ve Uşak Nuri Şeker Şeker Fabrikası karşısında depoları yer almakta; ayrıca Güre'de bir asfalt şantiyesi bulunmaktadır. Şube hizmet sınırları içinde yaklaşı 35 personel karayollarının, yol, çizgi ve işaretlerinin bakımı, onarımı ve kışları yolların tuzlanması gibi işlerde hizmet vermektedir.

Bir bölgede veya yerleşmede karayollarında kullanılan araç sayısı da şehir içi ve şehirler arası karayollarının planlanmasında kullanılabilecek önemli göstergelerdendir. Ayrıca taşıt sayıları şehiriçi trafik yoğunluğu hakkında da bilgi vermeleri açısından önemlidir.

Tablo 2. Uşak’ta Farklı Yıllara Göre Kayıtlı Araç Sayısı

\begin{tabular}{|l|c|c|c|c|}
\hline Araç Cinsi & $\mathbf{1 9 9 9}^{*}$ & $\mathbf{2 0 0 1}^{*}$ & $\mathbf{2 0 1 2}$ & $\mathbf{2 0 1 3}$ \\
\hline Motorsiklet & 9683 & 10133 & 14000 & 13587 \\
\hline Otomobil & 20235 & 22592 & 33449 & 37397 \\
\hline Minibüs & 1086 & 1206 & 1447 & 1441 \\
\hline Otobüs & 477 & 553 & 824 & 914 \\
\hline Kamyonet & 2805 & 3580 & 9750 & 10614 \\
\hline Kamyon & 2477 & 2487 & 1802 & 1747 \\
\hline Traktör & 11014 & 11619 & 8329 & 8496 \\
\hline Çekici & - & - & 421 & 505 \\
\hline Özel amaçlı araç & - & - & 156 & 172 \\
\hline Tanker & - & - & 98 & 100 \\
\hline Arazi taşıtı & - & - & 76 & 57 \\
\hline Römork & - & - & 7 & 5 \\
\hline Yarı römork & - & - & 489 & 586 \\
\hline Diğer & 183 & 263 & - & - \\
\hline Toplam & 48101 & 52433 & 70.848 & 75,621 \\
\hline
\end{tabular}

Kaynak: 2012 ve 2013 yılları: Uşak Trafik Tescil Büro Amirliği verileri; 1999-2001 y1llar1: (Yayla, 2001).

Merkez ilçede araç sayılarına bakıldığında toplam araç sayısı bakımından 1999'dan günümüze, az çok dikkat çekici bir artışın olduğu görülmektedir. Bu artışın otomobillerde ve otobüslerde daha fazla olduğu görülmektedir. Otobüs sayısının artmasında 2003 yılında kurulan Uşak merkezli bir firma olan Anadolu Turizm'in etkisi yüksektir. Artan şehir nüfusuna bağlı olarak minibüslerin de sayısının arttığı dikkat çekmektedir. Tarımsal alanlarda nüfusun azalmasına bağlı olarak traktör sayısı ise 1999'a göre daha düşüktür.

* 1999 ve 2001 yılları tüm ile aittir. 
Ulaşım Sistemleri ve Uşak

(Tablo 2) Trafik Tescil ve Denetleme Şube Müdürlüğü verilerine göre 2013 yılında Uşak merkez ilçede 103.132 sürücü belgeli kişi yaşamaktaydı. Aynı yıl 3889 yeni sürücü belgesi verilmiştir.

Şehirleşme ve motorlu taşıt sayısındaki artışlar gelişmekte olan ülke ve şehirlerde yeterli kaynak ayrılmaz ise ulaşım problemleri doğurabilmektedir (Sandal, 2009). Trafik sıkışıklıkları, kazalar bu tip sorunlara örnek olabilirler. D-300 karayolunun Uşak'ın içinden geçmesi trafik yoğunluğu ve kaza riski açısından en büyük problemdir (Yayla, 2001). Uşak merkez ilçede 2011 yılında 582, 2012 yılında ise 821 trafik kazasının olduğu görülmektedir (Tablo 3). Bu kazaların büyük çoğunluğunun da adı geçen yol üzerinde olduğu dikkat çekmektedir. Örneğin 2011 yılında meydana gelen 2 kişinin hayatını kaybettiği 2, 2012 yılında meydana gelen 7 kişinin hayatını kaybettiği 6 ölümlü kazanın tümü bu yolda ya da yola olan bağlantıların şehirden geçen kısımlarında olmuştur. Ayrıca kayıtlara göre ilçede meydana gelen 821 kazanın 148'i D-300 karayolu üzerinde gerçekleşmiştir. Aslında trafik kazalarında meydana gelen ölümler verilen tablodaki sayıdan fazladır, çünkü kazaların emniyet tarafından tutulan kayıtlarında sadece olay yerindeki durum yazılmakta, ambulansta ya da sonradan hastanede gerçekleşen ölümler istatistiklere yansımamaktadır. Uşak ili genelinde 1999 yılında 983 şehiriçi, 326 şehirdışı bölgede trafik kazası meydana gelmiştir (Yayla, 2001). İl genelinde 2012 yılındaki toplam kaza sayısı 1065'tir. Yolların kalitesinin ve bölünmüş yolların her geçen gün artmasına rağmen kazaların sayısında önemli bir azalmanın görülmemesinin nedeni, araçların bölünmüş yollarda sürat yapması ve sürücü hatalarına bağlanabilir. Trafik Tescil ve Denetleme Şube Müdürlüğü kayıtlarına göre 2012'deki 1065 kazanın 821'inin, Uşak merkez ilçede olmasından kaza sıklığının kentsel yoğunlukla ilişkili olduğu görülmektedir.

Tablo 3. Uşak Şehrinde Meydana Gelen Kazaların Türlerinin Dağılışı, Ölü ve Yaralı Sayıları

\begin{tabular}{|l|l|l|}
\hline KAZALAR & $\mathbf{2 0 1 1}$ & $\mathbf{2 0 1 2}$ \\
\hline Ölümlü Kaza & 2 & 6 \\
\hline Yaralamalı Kaza & 320 & 386 \\
\hline Maddi Hasarlı Kaza & 260 & 429 \\
\hline Toplam Kaza Sayıs1 & 582 & 821 \\
\hline Ölü Sayısı & 2 & 7 \\
\hline Yaralı Sayısı & 541 & 609 \\
\hline
\end{tabular}

Kaynak: Trafik Tescil ve Denetleme Şube Müdürlüğü verileri.

\section{Demiryolları}

Uşak ilinde ve şehrinde, önemli bir yere sahip olan diğer bir ulaşım sistemi de, demiryollarıdır. Anadolu'ya döşenen ilk demiryolu hatlarından olması bakımından tarihi bir değere sahip olan bu ulaşım sistemi, kentin ikamet sahalarının yayılma yönü üzerinde de önemli etkiye sahip olmuştur. Çeşitli çalışmalarda demiryollarının ulaştığ yerleşmelerin, bölgede gelişen ekonomik ve sosyal hayat sayesinde zamanla bir cazibe ve çekim merkezi olabileceğine değinilmiş; istasyona sahip yerleşmelerin nüfuslarının olmayanlara göre daha hızlı arttığından bahsedilmiştir (Yücel, 1960). Bu durumdan Uşak şehrinin de etkilendiği açıkça görülmektedir. 1950’li yıllara kadar meskenlerin şimdiki kadar dağılış göstermediği gar ve çevresi, bahsedilen yıllardan sonra yoğun bir iskân alanı haline gelmiştir. Günümüzde 
demiryolu bu sebeple yerleşim alanının içinde kalmış̧ır (Bilgen, 1999). Demiryollarının hattın geçtiği güzergâhta Uşak ili sınırları içinde sosyo-ekonomik yapıdaki değişim sadece il merkezinde görülmemiştir ${ }^{3}$. Eşme ilçesine bağlı Elvanlı ve Ulubey ilçesine bağglı İnay'da da yeni yerleşim nüveleri oluşmaya başlamıştır (Ceylan, 2010a; Ceylan, 2010b).

Uşak'ta demiryollarının durumunu incelemeden önce tarihi önemi olan bu hattın geçmişine değinmekte fayda vardır. 19. yy.'in başında lokomotifin İngiltere'de icat edilmesi demiryolları için bir milat olmuş (Karabulut, 1997) ve aynı yüzyılın ortalarından itibaren demiryolları dünyanın en önemli ulaşım aracı olmaya başlamışıır (Yıldırım, 2001). Yük ve yolcu taşımacılığında kullanımının gittikçe artmasıyla dünyanın birçok bölgesinde demiryolu ağları döşenmeye başlanmıştır. Osmanlı Devleti de bu gelişmeye kayıtsız kalamamış ve devletin ilk demiryolları döşenmeye başlanmıștır. Farklı bölgelere döșenen hatlar Anadolu'daki merkezi demiryolu hatları, merkezi güneye bağlayan hatlar ve İstanbul üzerinden Avrupa'ya bağlantıyı kuran hatlar şeklinde tasarlanmıştır (Bakırcı, 2013). Bu ulaşım aracı için seçilen güzergâhlarda çeşitli amaçlar güdülse de özellikle Batı Anadolu'da kurulan hatlarda bölgenin ekonomik çeşitliliği ve önemli ürünleri etkili olmuştur (Akbulut, 2010). Bu sebeple bölgenin dünyaya açılan ticari limanı olan İzmir ve hinterlandındaki önemli merkezler, hattın geçtiği güzergâhlarda belirleyici olmuşlardır. Limanı, gelişmiş ticaret hayatı ve hinterlandındaki kıymetli ürünler, madenler vb. nedenlerle Batı Anadolu ve Osmanlı Devleti'nin önemli ticaret merkezlerinden olan İzmir, demiryolları için önemli bir başlangıç ve düğüm noktası olmuştur. Böylece Anadolu'da döşenen ilk demiryollarının İzmir ve çevresinde kurulan İzmir-Aydın ve İzmir-Kasaba hatları oldukları görülmektedir. ${ }^{4}$ Ayrıca bu hatların daha sonra Anadolu içlerine uzatılmasıyla İzmir'in ticari öneminin daha da artacağı hesap edilmekteydi (Uzuntepe, 2000).

Batı Anadolu'da yolcuların ve üretilen malların taşınmasında kullanılmak amacıyla yapılan ve Anadolu'ya döşenen ilk hatlar olan bu iki güzergâhtan araştırma sahasını ilgilendireni İzmir-Kasaba demiryolu hattıdır. Devletin bu hatları yapacak ekonomik gücünün olmaması sebebi ile farklı ülkelere imtiyazlar verilerek demiryollarının döşenmesi yoluna gidilmiş; İzmir-Kasaba hattının imtiyazı da başlangıçta İngilizlere sonra da Fransızlara devredilmiştir (Akbulut, 2010). Bu hattın yapımına kimi kaynaklara göre 1864 ya da 1865 yılında başlanmış ve hat 1865 'te Manisa'ya ulaşmıştır (Çağlıyan ve Bozkurt Yıldız, 2013; Satan, 2012). Kaynaklarda farklı tarihlerin verildiği görülmekle beraber uzatılan hattın 117,8 km' lik Alaşehir-Uşak arası 1897'de, 134,9 km'lik Uşak-Afyonkarahisar arası ise $1898^{\prime}$ 'de açılmıştır (Ceylan, 2010a) ${ }^{5}$. Benzer bilgilere yer veren diğer bir araştırmada,

${ }^{3}$ Demiryollarının Batı Anadolu'da yaptığı etkiler için Bkz. (Akbulut, 2010; Kurmuş, 1982; Pamuk, 1994)

${ }^{4}$ İzmir'in, Batı Anadolu'nun ticari potansiyeli, ilk demiryolu güzergâhları ve İzmir- Aydın demiryolu hakkında Bkz. (Kurmuş, 1982); İzmir-Kasaba demiryolu hakkında ayrıntılı bilgi ve önemli tarihler için Bkz. (Doğanay, 2011; Satan, 2012)

${ }^{5}$ Ceylan (2010a)'da TCDD'nın demiryolu hatlarının açılışı konusunda farklı tarihler verdiği tespit edilmiştir. Bu hususta http://www.tcdd.gov.tr/genel/acilistarihleri. htm internet sitesi kaynak gösterilmektedir. 
Ulaşım Sistemleri ve Uşak

1899 yılında hattın Anadolu demiryolu hattı ile birleştirilmesi ile Uşak'ın ulaşım imkânlarının iyice arttığına değinilmektedir (Çakmak, 2008).

Ülkemizde karayollarının geliştirilip önemli bir ulaşım ağı kurmasına kadar Uşak'ta önemini koruyan bu ulaşım şekli zamanla eski önemini kaybetmiştir. Günümüzde gerek Uşak şehrinde gerekse ilçe genelinde en önemli ulaşım şekli karayolları olmasına rağmen demiryollarının önemsiz olduğu da söylenemez.

Uşak Gar Müdürlüğü’ne bağlı birimler 35. Yol Bakım Müdürlüğü, Emlak Şefliği, 33. Haberleşme Şefliği, Bölge Kısım 33. Şefliği, Lojistik Müdürlüğü ve Depo Şefliğgidir. Birimler 1891-1892 yıllarında inşa edilen tarihi binalar ve ona ek olarak yapılan binalarda hizmet vermektedirler (Foto 2). Yapılan mülakatlara göre şehirde demiryolu taşımacılığında yaklaşık 98 kişinin istihdam edildiği tespit edilmiştir. Gar müdürlüğünde 6 tren teşkil memuru, 5 hareket memuru, 3 gişe memuru ve 2 geçici personel görev yapmakta ve yolcu taşımacılığına hizmet etmektedir. Geri kalan personel ise diğer birimlerde çalışmaktadır.

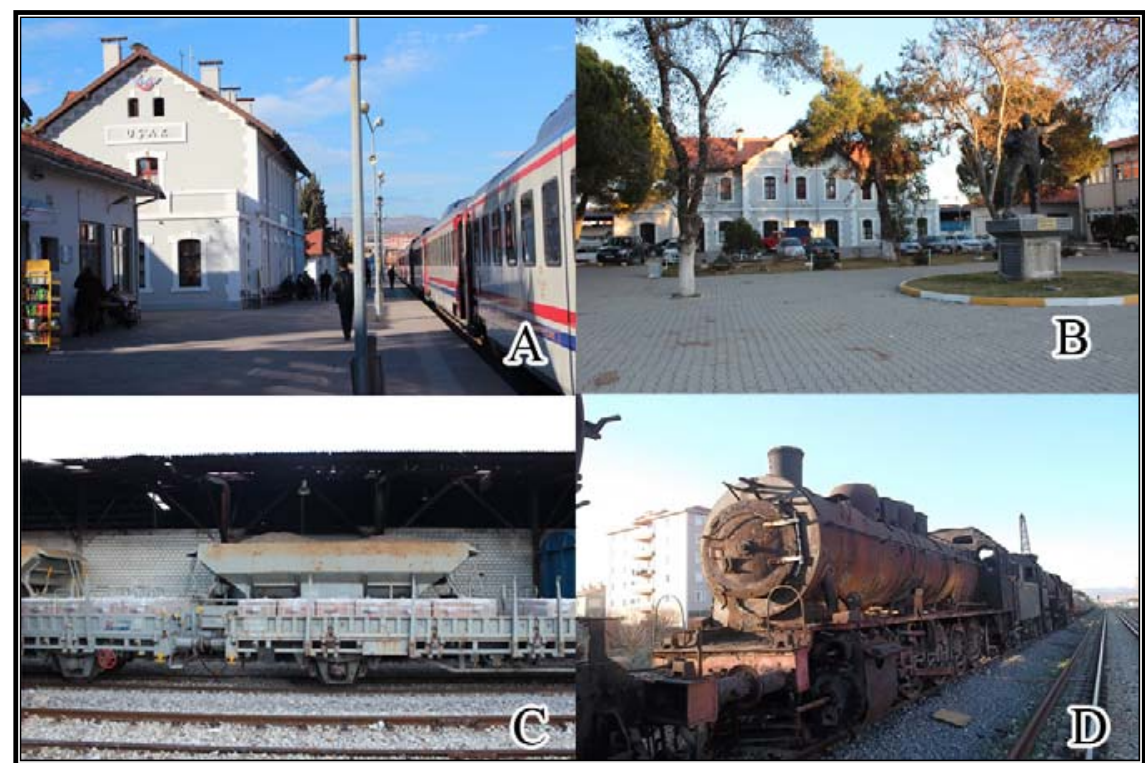

Foto 2. Uşak Garından Farklı Görünümler (A.-B. Uşak Garı Tarihi Binaları ve Yolcu Peronları; C. Yüklenmiş Seramikler; D. Tarihi Lokomotifler)

Uşak'tan İzmir-Konya ve İzmir-Ankara arasından günde 1'er karşılıklı sefer yapılmaktadır. Uşak bu güzergâhlar arasında transit seferlerin olduğu bir durak konumundadır. Ayrıca kalkış ve varış noktası Uşak olan, İzmir-Uşak arasında hizmet veren karşılıklı 2 farklı seferle gara günde 8 yolcu treni uğramaktadır. Bu güzergâhlarda sefer başına İzmir-Konya arasında 360-420, İzmir-Ankara 450, Uşak-İzmir arasında 300 yolcu kapasitesi yer almaktadır. Yapılan mülakatlarda, Uşak’tan binen yolcuların yaklaşık \%90'ının İzmir'e seyahat ettiği öğrenilmiştir. Ayrıca Alaşehir ve Eşme dolaylarına 
seyahat edenler, karayolu taşımacılığının bu bölgede çok düzenli olmaması sebebiyle demiryolunu özellikle tercih etmektedir.

Garda yapılan mülâkatlardan elde edilen bilgiye göre daha ziyade yaşlıların, dar gelirlilerin ve engellilerin tercih ettiği belirtilmiştir. Demiryolu yolcu taşımacılığında, yolcu yoğunluğu yaz aylarında artmaktadır. Ayrıca okulların açılma ve tatile girme dönemlerinde, yoğunlukta artış görülmektedir. Bu dönemlerde normalde 5-6 vagon olan günlük yolcu kapasitesi 8-9 vagona kadar çıkmaktadır.

Demiryollarının tercih edilmemesinin en önemli sebebi yolculuk süresinin çok uzun olmasıdır. Her ne kadar ekonomik olsa da karayolları ile yaklaşık 3 saat süren İzmir, 287 km'lik demiryolu vasıtasıyla 6 saat sürmektedir. Bu sebeple yolcular demiryollarını tercih etmemektedir. Ayrıca zaman zaman araçların eskimiş olmasına bağlı olarak yolda kalmalar ya da trafik nedeniyle beklemeler de seyahat süresini arttırmakta, bu da yolcuların demiryollarını tercih etmemelerine sebep olmaktadır. Uşak garında yaptığımız mülakatlar ve gar istatistiklerine göre 2013 yılı içinde 116.228 yolcu Uşak'ta demiryolları ile seyahat etmeyi tercih etmiştir (Tablo 4).

Tablo 4. Ușak Garından Taşınan Yolcu Sayısı ve Geliri

\begin{tabular}{||c|c|c|}
\hline Y1llar & Yolcu Adedi & Yolcu Geliri (TL) \\
\hline 2010 & 94891 & $365.070,00$ \\
\hline 2011 & 113907 & $503.952,00$ \\
\hline 2012 & 106384 & $558.508,50$ \\
\hline 2013 & 116228 & $703.197,00$ \\
\hline
\end{tabular}

Kaynak: Uşak Gar Müdürlüğü İstatistikleri

Uşak garı, yolcu taşımacılığının yanında yük taşımacılığında da hizmet vermektedir. Yıllar itibari ile değişmekle beraber yılda 1000 vagondan fazla yük gelmekte yine 1000 vagondan fazla yük ise Uşak Garı lojistik biriminde yüklenmektedir. Örneğin 2013 yılında 1157 vagondan 31,146 ton yük Uşak Garı'nda indirilirken, aynı yıl 1016 vagonda 50,900 ton yük Uşak'tan gitmiştir (Tablo 5). Lojistik biriminde yük taşımacılığında kullanmak amacıyla yükleme-boşaltma rampaları, manevra makinaları, döner köprüler ve 100 tonluk bir kantar bulunmaktadir.

Tablo 5. Ușak Garı lojistik Biriminden Tașınan Yük Miktarı

\begin{tabular}{|l|c|c|c|c|}
\hline & \multicolumn{2}{|c|}{ Gelen Yük } & \multicolumn{2}{c|}{ Giden Yük } \\
\hline Y1llar & Vagon Adedi & Tonaj1 & Vagon Adedi & Tonaj1 \\
\hline 2011 & 1195 & 32,606 & 1598 & 69,581 \\
\hline 2012 & 1273 & 38,316 & 1418 & 67,088 \\
\hline 2013 & 1157 & 31,146 & 1016 & 50,900 \\
\hline
\end{tabular}

Kaynak: Uşak Gar Müdürlüğü İstatistikleri

Bölgede 2006 yılından itibaren taşımacılık blok yük taşıması şeklindedir. Bu sebeple yükün taşınabilmesi için belirli bir yük miktarı beklenmektedir. Taşınan ham ve mamul maddelerin daha hızlı ulaştırılabilmesi amacıyla Uşak’ta yük taşımacılığı Afyon ve İzmir ile koordineli olarak çalışmaktadır. Karşılıklı olarak yeterli yük, vagon, lokomotif ve makinist bulunduğu takdirde ek seferler düzenlenebilmekte ya da ara istasyonlarda 
Ulaşım Sistemleri ve Uşak

yüklenecek yük var ise trenler beklenen saat ya da günden önce hareket ederek daha erken yola çıkarılabilmektedir.

Yük taşımacılığında yoğunluk, daha çok inşaat sektörü ile ilgilidir. Uşak'tan taşınan yükün neredeyse tamamını oluşturan seramiklere olan talep inşaat sektörünün canlandığı yaz aylarında artmakta, bununla birlikte Uşak'tan taşınan yükün miktarı da artmaktadır (Foto 2). Yoğunluğun en düşük olduğu dönem ise aralık ve ocak aylarıdır. Uşak Garı yöneticileri ile yapılan görüşmede taşınan yükün \%80'inin yaz sezonunda taşındığı belirtilmiştir.

Ayrıca yükün miktarında Uşak'ta bulunan fabrikaların ticari ilişkilerinin, yönetimsel değişikliklerin de önemli etken olduğu belirtilmiştir. Örneğin fabrikaların üretimde ya da satışta yaşadığı sorunlar dolaylı olarak Uşak Garı'ndaki yük taşımacılığına da yansımaktadır. Ayrıca fabrikalardaki yönetim değişiklikleri de taşıma aracının tercihinde veya seramik satışlarında değişime neden olduğundan yük taşımacılığı da bu durumdan etkilenmektedir.

Uşak’ta önemli seramik üreticilerinden olan Hitit, Umpaş ve Uşak seramik fabrikaları demiryolları ile taşınan yükün en önemli sahipleridir. Uşak’tan yüklenen seramikler özellikle adı geçen fabrikaların önemli alıcılarının bulunduğu bölgesel dağıtım merkezlerine gönderilmektedir. Yükün büyük kısmının taşındığ 1 başlıca merkezler: Gaziantep, Diyarbakır, Mardin, Kahramanmaraş ve Elazı̆̆' dır. Uşak'tan yüklenen seramikler en uzak merkez olan Diyarbakır'a yaklaşık iki ya da 3 gün gibi bir sürede ulaştırılmaktadır.

Geçmişte, İzmir Limanı'na ihracat amaçlı da yük taşınmaktaydı. Mamul maddeler Organize Sanayi Bölgesi'nden gara getirilmekte ve yüklenmekteydi. Yaptığımız mülakatlarda o dönemler taşınan yük miktarının bugünkü miktarın en az ki katı kadar olduğu öğrenilmiştir. Ancak yükün sanayi bölgelerinden gara getirilmesi için karayolu araçlarına yüklenmesi ve garda yeniden indirilmesi sıkıntı olduğu için günümüzde firmalar yüklerini İzmir Limanı'na doğrudan karayolları ile taşımayı tercih etmektedirler.

Uşak'a gelen yükün büyük çoğunluğunu ise Mersin'den getirilen fenni gübre oluşturmaktadır. İthalat yolu ile getirilen gübreler Mersin Limanı'ndan yüklenmekte ve demiryolu aracılığıyla Uşak'a taşınmaktadırlar. Son yıllarda Ortadoğu'da yaşanan siyasi kargaşa ve iç savaşlar nedeniyle bölge ülkeleri ile olan ticaret de olumsuz etkilenmiştir. $\mathrm{Bu}$ olumsuzluklar Uşak'ta taşınan yük miktarının azalmasına neden olmuştur. Çünkü bunalımlı bu dönemden önce Suriye ile karşılıklı ithalat ihracat yapılmakta ve yükün bir kısmı da demiryolları vasıtası ile taşınmaktaydı. Özellikle Suriye'deki iç savaş ülke ile olan ihracatı iyice azaltmıştır. Uşak'tan Suriye'ye geçmişte battaniye, bebek bezi, dokuma ipliği ihraç edilirken, geri dönüşüm sektöründe kullanılmak amacıyla Suriye'den iplik artıkları ithal edilirdi.

Uşak’ta geçmişte yapılan, günümüzde ise sürdürülmeyen başka bir taşımacılık da Uşak Şeker Fabrikası'na olan mamul ve hammadde taşımacılığıdır. Uşak Şeker Fabrikası'nın 
taşımacılıkta demiryollarını kullandığı dönemde fabrikaya iltisak hattı ${ }^{6}$ ile bağlanan demiryolları aracılığı ile melas, şeker pancarı, kömür vb. yükler de taşınmaktaydı. Ancak günümüzde bu tesis, taşımacılıkta karayollarını tercih etmektedir.

\section{Havayolları}

Hava ulaşımının peyzajdaki en önemli öğesi havalimanları ve havaalanlarıdır. Geçmişte hava ulaşımı ile ilgili yapılan çalışmalarda taşınan yük ve yolcu sayısına göre havalimanları ve havaalanları ayrı ayrı incelenmiştir (Taşlıgil, 1996; Öz, 2002). DHMİ Genel Müdürlüğü de uluslararası uçuşlara açık, gümrük vb. donanımları bulunan, yük ve yolcu taşımacılığında önemli sayılara sahip meydanları havalimanı, hava araçlarının iniş-kalkış ve yer hareketlerini gerçekleştirebilmeleri için yapılmış daha küçük meydanları ise havaalanı şeklinde adlandırmaktaydı (DHMİ Genel Müdürlüğü, 2011). Ancak yapılan bazı düzenlemeler ile isim karışıklığının önüne geçmek amacıyla meydanların tamamı havalimanı şeklinde anılmaya başlanmıştır. Bu sebeple çalışmamızda havalimanı terimi kullanılmıştır. Zaten yapılan son değişimlerle meydanda gümrük de tesis edilmiştir.

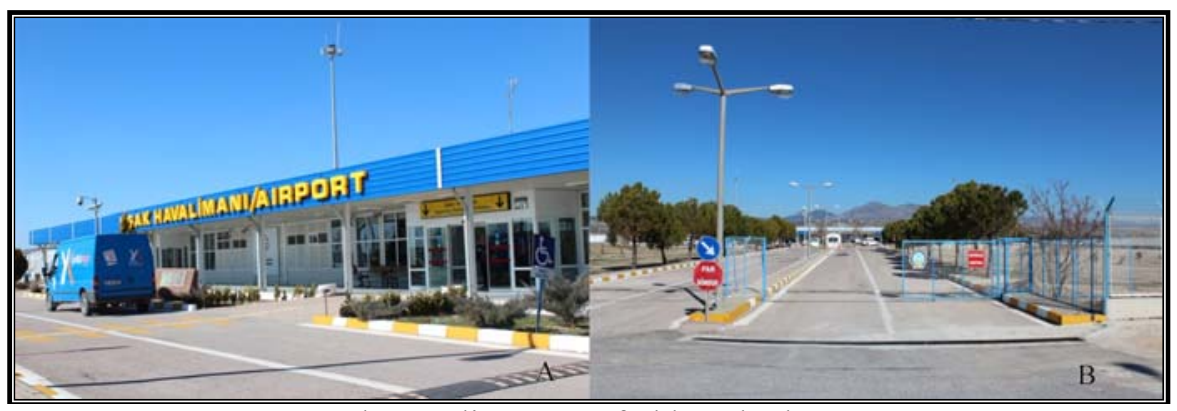

Foto 3. Uşak Havalimanı'nın farklı açılardan görünümü

20 Haziran 1998 yılında hizmete açılan Uşak Havalimanı 2560 m uzunluğunda ve 30 m genişliğinde bir piste sahiptir. 2001 yılına kadar hizmet veren ancak bu yıl talep azlığı nedeni ile kapatılan tesiste 2006 yılında yeniden seferlere başlanmıştır (Taha Orhan Planlama Mühendislik İnşaat Enerji ve Turizm AŞ., 2012). İzmir-Ankara (D-300) karayolu üzerinde şehrin doğusunda yer alan Uşak Havalimanı şehre yaklaşık 7 km uzaklıktadır. 2006 yılında sivil havacılık hizmetlerine yeniden açılan havalimanı tarifeli seferlere 2011 yılında tekrar kapatılmıştır. Bu tarihten 2014 yılının başına kadar tarifeli seferlerle uçuş bulunmamaktadır. Terminal binasının alanı yaklaşık olarak $1460 \mathrm{~m}^{2} \operatorname{dir}$ (İnternet 5.). Havalimanının kente yakın olması dolayısı ile ulaşım problemi bulunmamaktadır. Taksi ya da servisler ile kolayca ulaşmak mümkündür. Tesis bünyesinde 90 kişi hizmet vermektedir (Tablo 6.).

${ }^{6}$ İltisak Hattı (Connection Line): Ana demiryolu hatlarından önemli depo, fabrika, sanayi bölgeleri vb. tesislere giden demiryolu bağlantı hattı-tali hat. Bkz. http://www.lojistiksozluk.com/iltisak-hatti.html (12.02.2014) 
Ulaşım Sistemleri ve Uşak

Tablo 6. Uşak Havalimanında Çalışan Personel Sayısı

\begin{tabular}{|l|c|l|c|}
\hline Bağ̆ı Olduğu Birim & Sayısı & Băğı Olduğu Birim & Sayısı \\
\hline DHMİ Personeli & 55 & Temizlik Hizmetleri & 7 \\
\hline Polis & 10 & Teknik Personel & 9 \\
\hline Meteoroloji & 5 & Borajet Firması & 4 \\
\hline
\end{tabular}

Kaynak: Yerinde yapılan gözlem ve mülakatlar.

Güvenli bir hava ulaşımının sağlanabilmesi için havaalanlarının yapılacağı konumların doğal coğrafi şartları önem arz etmektedir (Kadığ̆lu, 2007). Uşak Havalimanı'nda pist düşük eğim şartlarının bulunduğu ovalık alanda doğu-batı istikametinde yapılmıştır. Kısa mesafede bu doğrultuda dağlık alanın bulunmaması nedeniyle iniş ve kalkışlar için tehlike oluşturabilecek bir topoğrafik engel yer almamaktadır. Hava muhalefeti nedeniyle iniş ve kalkışlarda erteleme ve pistte pas geçiş olayına rastlanılmamaktadır. Uçuşlardaki gecikmeler daha ziyade uçakların geldikleri havalimanlarındaki hava durumu ya da oradaki pist trafiği ile alakalı rötarlardan kaynaklanmaktadır.

10 Ocak 2014 tarihinden itibaren Borajet firmasının Uşak Havalimanı'ndan İstanbul'a (Sabiha Gökçen Havalimanı) düzenli seferler yapmaya başlamasıyla tesis yeniden hareketlenmiştir. 2014 yılı ocak ve şubat aylarında 1346 yolcu Uşak Havalimanı'nı kullanmıştır ${ }^{7}$. Uçuşlar haftada üç gün gerçekleştirilmektedir. Geçmişte Ankara Esenboğa Havalimanı'na da seferler yapılmakta ise de talep yetersiz olduğu için artık buraya tarifeli seferler düzenlenmemektedir.

Uşak havalimanından hava taksileri, eğitim, ambulans, askeri ve iş amaçlı uçuşlar için de faydalanılmaktadır. Örneğin 2014 ocak ve şubat ayları içinde 82 eğitim, 6 yurtiçi ambulans, 2 yurtdışı ambulans, 2 askeri, 4 hava taksisi 2 de iş amaçlı özel uçak Uşak Havalimanı'nı kullanmıştır.

Eğitim amaçlı uçuşlar karşılıklı protokollerin imzalandığı, Anadolu Üniversitesi, İstanbul Havacılık Kulübü, Türk Hava Kurumu Üniversitesi, Ege Havacılık, THY, Er-Ah, TARKİM Uçuş Okulu adlı kurum ve kuruluşlar tarafından yaptırılmaktadır. Ayrıca Uşak Üniversitesi'nin de çok yoğun bir trafiği olmayan hava limanından faydalanmak amacıyla havacılık üzerine eğitim veren bölümleri açması planlanmaktadır.

Havalimanının uçaklar tarafından kullanılma nedenleri arasında askeri ve sağlık amaçlı uçuşlar da yer almaktadır. Havalimanına askeri amaçlı uçaklar yakıt ikmali yapmak için ve özel uçuşlar amacıyla uğramaktadırlar. Ayrıca tesisten acil durumlarda sağlık amaçlı uçuşlar ya da cenaze taşınması için de faydalanılmaktadır.

Uşak havalimanından taşınan yolcu sayısında 2001 yılında ulaşıma ara vermeden önceki dönem ile 2006 yılında ulaşıma yeniden kazandırılmasından sonraki dönem arasında sayı bakımından önemli bir fark bulunmaktadır (Tablo 7 ve Tablo 8). Bu durumun oluşmasında Türkiye'nin hava ulaşımı alanındaki yatırımlarının ve politikalarının etkisinin

7 Araştırmanın tamamında havayolları ile ilgili şubat ayı verileri mülakatların gerçekleştirildiği 20 Şubat tarihine kadar olan sayıları içermektedir. 
olduğu söylenebilir ancak tesisin hâlâ istenen seviyede olduğunu ve hava yolu ulaşımında önemli bir yerde olduğunu söylemek güçtür. DHMİ verilerine göre, 2011 yılında Türkiye çapındaki havalimanlarında yurtiçi ve uluslararası seferlerde uçak trafiğinin 1.042.369, taşınan yolcu sayısının ise 117.620 .469 olduğu düşünülünce bu daha net ortaya çıkmaktadır. Aynı yıl 47 havalimanı içinde uçak trafiği bakımından 40. sırada olan meydan, yolcu sayısı bakımından Gökçeada, Balıkesir, Kocaeli, Antalya Gazipaşa havalimanlarının üzerinde 43. sıradadır. 2011 yılında 15.267 kişi ile Türkiye havalimanlarını kullanan yolcuların sadece \% 0,01 'i Uşak havalimanını tercih etmiştir. Hava trafiği açısından ise aynı yıl iniş kalkış yapan 706 uçak, toplam uçak sayısının yaklaşık \% 0,06’sını oluşturmuştur (Tablo 8).

Uşak havalimanının yurtdışı uçuşlarda pek kullanılmadığı Tablo 7. ve Tablo 8'de görülmektedir. Nitekim 2007-2012 yılları arasını içeren dönemde dış hatlara, sadece 28 uçuş yapılmıştı. Yurtdışına yapılan seyahatler için tarifeli seferler bulunmamakta, uçuşlar charter veya charter flight olarak adlandırılan tarifesiz uçuşlar şeklindedir. Bu tip uçuşlar, Uşak'a özel amaçlı ya da sağlık amaçlı seyahatler için yapılmaktadır. Havalimanında yapılan mülakatlardan yurtdışı seferlerin daha çok Avrupa ülkeleri ile gerçekleştiği, geçmişte Belçika, İsviçre, Danimarka, Yunanistan, İtalya, Sırbistan, Romanya ve Almanya'ya giden ya da bu ülkelerden gelen uçakların olduğu öğrenilmiştir. Ancak düzenli seferlerin olmaması sebebiyle belirli bir güzergâhta yoğunluktan söz edilemez. Yurtdışı uçuşlar ile gelenler daha ziyade organize sanayi bölgelerinde faaliyet gösteren firmalar ile ticaret maksadiyla ve Eşme ve Ulubey ilçesi sınırlarında kalan Kışladağı'ndaki altın madeninde görüşmeler yapmak amaciyla gelmektedir.

Tablo 7. Uşak Havalimanından Ulaşıma Ara Vermeden Önce Taşınan Yolcu Sayısı

\begin{tabular}{|l|c|c|c|}
\hline \multirow{2}{*}{ Yıllar } & \multicolumn{2}{|c|}{ Uçak Trafiği (Gelen-Giden) } & \multirow{2}{*}{$\begin{array}{c}\text { Yolcu Sayısı } \\
\text { (Gelen-Giden) }\end{array}$} \\
\cline { 2 - 4 } & İç Hatlar & Dış Hatlar & 0 \\
\hline 1998 & 49 & 0 & 1236 \\
\hline 1999 & 254 & 0 & 1936 \\
\hline 2000 & 250 & 0 & 15 \\
\hline
\end{tabular}

Kaynak: (Öz, 2002: 27)’den yararlanılmıştır.

Tablo 8. Uşak Havalimanına Gelen Yolcu Sayısı ve Uçak Trafiği

\begin{tabular}{|l|c|c|c|}
\hline \multirow{2}{*}{ Yıllar } & \multicolumn{2}{|c|}{ Uçak Trafiği (Gelen-Giden) } & \multirow{2}{*}{$\begin{array}{c}\text { Yolcu Sayısı } \\
\text { (Gelen-Giden) }\end{array}$} \\
\cline { 2 - 3 } & İç Hatlar & Dış Hatlar & 31.328 \\
\hline 2007 & 513 & 0 & 25.305 \\
\hline 2008 & 430 & 2 & 10.327 \\
\hline 2009 & 288 & 0 & 15.889 \\
\hline 2010 & 314 & 10 & 15.267 \\
\hline 2011 & 701 & 5 & - \\
\hline 2012 & 683 & 11 & \\
\hline
\end{tabular}

Kaynak: http://www.dhmi.gov.tr/istatistik.aspx (20.02.2014) 


\section{SONUC}

Türkiye'de uygulanan 2000 genel nüfus sayımına göre Uşak merkez ilçede 1394 kişi ulaştırma, haberleşme ve depolama gibi hizmet sektörlerde çalışıyordu (DİE, 2002). SGK (Sosyal Güvenlik Kurumu) 'nın 2014 yılı kayıtlarına göre ise aynı sektörlerde çalışan kayıtlı işgücü 2747'dir. Bunda karayolu, demiryolu ve havayollarının payı \% 87,5 (2403) dolayındaydı.

Tarafımızca yapılan saha gözlemleri ve mülakatlarda da karayolu, demiryolu ve havayollarında yaklaşık 2689'un üzerinde kişinin gelir elde ettiği tespit edilmiştir. Bu haliyle ulaşım sektörünün ilçede önemli bir ekonomik faaliyet olduğu görülmektedir.

Önemli sayıda bir nüfusun (2014'de yaklaşık 2689) temel geçim kaynağı olan bu sektörün belirli sorunları olduğu dikkat çeker. Öncelikle, ulaşımın daha rahat ve güvenli yapılabilmesi için bazı önlemlerin alınması gerekir. Örneğin; D-300 karayolu üzerinde stadyum kavşağı (Zübeyde Hanım Caddesi ve D-300 karayolunun kesişimi), şehirlerarası otobüs terminalinin bulunduğu semte; Dikilitaş kavşağı (D-300 karayolu ile Barbaros Caddesi'nin kesişimi) çevresine alt ve üst geçitli büyük kavşakların yapılması trafiğin kolay akışı açısından isabetli olacaktır. Ayrıca D-300 karayolu yakınına yapılan yeni hastanenin bulunduğu alan da yeni bir yoğunluk bölgesi olarak karşımıza çıkmaktadır. Şehirlerarası ulaşımda önemli olan yol üzerinde yüksek süratle hareket eden araçlar, hasta araçları ve ambulanslar sık sık karşı karşıya gelmektedir. Ayrıca adliye sarayının da yakın bir zamanda buraya taşınacak olması sebebiyle bu kavşağın yerine alt ve üstgeçitli büyük bir kavşağın yapılması gereklidir. Bu kesimde karşılaşılan önemli bir ulaşım problemi de D-300 karayolundan hastaneye ayrılan tali yolun, demiryolu ile kesilmesi ve bir hemzemin geçidin burada yer almasıdır. Demiryolu araçlarının geçişi sırasında bu yol ulaşıma kapanmakta ve ulaşımda kesinti yaşanmaktadır. Özellikle demiryolu araçlarında meydana gelebilecek arızalarda bu kesinti uzun bir zamana yayılabilir. Ambulansların ve acil hastaların hastaneye ulaşımı bu gibi dönemlerde trenin hareket etmesine bağlıdır ve böyle bir durum acil hastalar için hayati öneme sahiptir. Bu sebeple buradaki hemzemin geçitte acil önlemlerin alınması alt ya da üst geçitlerle karayolu ulaşımının devamlılı̆̆ı sağlanmalıdır.

Şehir planının ve eski imar planlarının daha az bir nüfusa göre yapılmış olması nedeniyle, bu gün özelikle İsmet Paşa Caddesi gibi şehrin MİA'sını oluşturan semtlerde ulaşım, büyük problem oluşturmaktadır. Şehiriçi trafik probleminin yoğun olarak yaşandığg 1 mahalleler Özdemir, Köme, Ünalan, Kurtuluş, Durak ve İslice Mahalleleri sınırları içinde kalan bölgelerdedir. Özellikle İsmet Paşa, Zübeyde Hanım, Barbaros, Bir Eylül, Doğan Özkahraman, Fatih, Cumhuriyet ve Mimar Sinan Caddeleri şehir içi yoğunluğu kaldıramaz duruma gelmiş̧ir. İsmet Paşa Caddesi ve yakın çevresinde Hükümet Konağı, Orman İşletme Müdürlüğü, Adliye Sarayı, Milli Eğitim Müdürlüğü, Meteoroloji Müdürlüğü, Gençlik ve Spor İl Müdürlüğü, PTT ve Telekom, Bir Eylül Stadyumu, Kültür Müdürlüğü, Arkeoloji Müzesi, Maliye, Belediye, Öğretmenevi gibi kamu kurum ve yapıları çok yakın mesafelerde bulunmaktadır. Ayrıca aynı çevrede banka şubeleri, birçok eğitim kurumu, çeşitli sivil toplum kuruluşlarının yönetim binaları ve kentin ilgi çeken tarihi ve turistik çekiciliğe sahip mekânlarının da yer alması özellikle mesai saatleri içinde büyük bir yoğunluğun yaşanmasının en büyük sebeplerindendir. Geçmişte hastane ve çeşitli sağlık kurumlarının da 
burada yer alması yoğunlukta pay sahibi iken yeni yapılan devlet hastanesine çeşitli birimlerin taşınması ile buradaki yoğunluk kısmen azalmış ancak tam olarak çözülememiştir. Halen mevcut kurum ve kuruluşların bir arada olması özellikle toplu taşıma güzergâhlarının da buradan geçmesini zorunlu hale getirmektedir. Kentsel dönüşüm alanına bu kurum ve kuruluşların bir kısmının taşınacak olması önemli bir problemi de çözecektir. Belediye binası ve vergi dairesinin kentsel dönüşüm alanına, adliye sarayının ise yeni hastane karşısında şehrin periferisine taşınması için gerekli girişimler başlatılmıştır. Bu şehrin daha düzgün ve planlı bir gelişim göstermesinin yanında şehiriçi trafiğin de rahatlamasına önemli katkı sağlayacaktır.

Kent içi trafik açısından diğer bir olumsuzluk da, pazar yerleridir. Özellikle şehrin en önemli pazarı olan İslice ve Elmalıdere Mahallelerinde Çarşamba günleri kurulan semt pazarları da bu günlerde kent içi trafiğin kilitlenmesine sebep olmaktadır. Şehirde Cumartesi ve Salı günleri kurulan pazarlarda da benzer sorunlar yaşanmaktadır.

D-300 karayolundaki trafik yoğunluğu ve bu önemli yolun Uşak şehrinden geçmesi önceki çalışmalarda (Bilgen, 1999; Yayla, 2001) da dile getirildiği gibi kaza riskini arttırmakta, yolda ölümlü kazalar yaşanabilmektedir. Ayrıca İzmir-Ankara arasında trafiğe çıkan tüm araçların kente uğraması, kent içi trafik yoğunluğunu da olumsuz etkilemektedir. Uşak'ta şehir içine girmeden çevresinden dolaşacak bir çevre yolunun yapılması günümüzde bir zorunluluk halini almıştır. Bu sebeple kentin güneyinden geçecek olan yeni bir çevre yolunun yapımı sürdürülmektedir. Yeni çevre yolu, D-300 karayolunda OSB çevresinden ayrılarak, Eskisaray, Kayaağıl, Karaağaç gibi köylerin arazilerinden geçerek Bölme yoluna bağlanmaktadır. Oradan Denizli yoluna (D 595) ve İkisaray, Çarıkköy arasına yapılacak olan yeni şehirlerarası otobüs terminali yakınlarından yeniden D 300'e katılacak olan yol, kentin güneyinden geçerek şehir trafiğine yük olmaktan uzaklaşacaktır.

Çevre yolunun dışında şehir trafiğini ve D-300 üzerindeki yoğunluğu azaltacak diğer bir tasarı da kent yerleşim alanının kuzey ve güneyine yapılacak olan iki ana arterdir. Hacıkadem köyü, şehrin kuzey kısmı ve Akse Çamlığı arasına yapılması planlanan ve yapımlarına başlanan kuzey arteri, kentin batı kesiminde D-300 karayolundan ayrılarak kentin güneyinden geçen ve yeni Devlet Hastanesi'ne bağlanması planlanan güney arteri şehrin bu bölgelerinde oturan sakinlerinin D-300 karayoluna ve bu yolun önemli bir kavşağ olan Dörtyol mevkiine uğramadan doğu ve batı yönde yolculuklarını sürdürmelerine olanak sağlayacak yollardır.

Araştırma sahasındaki mevcut trafik sorunlarından bir diğeri de, alışveriş ve iş yerlerinin yoğunlaştığ (T.C. Uşak Valiliği Çevre ve Şehircilik İl Müdürlüğü, 2012). Bu sorun düşük ücretli, çok katlı yeni katlı otoparklar yapılarak, mevcut park yerleri ve bu otoparklara park etmeyi zorunlu duruma getirerek az çok önlenebilecektir.

Ülke ve bölgelerin kalkınma planlarının sağlıklı bir şekilde uygulanabilmesi için ulaştırma altyapısının tamamlanması veya iyileştirilmesi gerekmektedir (Sever, 2005). Uşak şehrinin ve ilinin güneydeki büyük merkezlere ulaşımını sağlayan D-595 karayolunun çift şeritli ve bölünmüş yol haline getirilmesine önem verilmelidir. Ayrıca Ulubey-Eşme istikametine giden 64-50 nolu il yolunda genişletme yapılmalıdır. 
Ulaşım Sistemleri ve Uşak

Ulaşım fonksiyon alanlarından olan hava meydanları; hava yolları ile ulaşımın olmazsa olmazıdır. Ancak yoğun olarak kullanılmayan havalimanları çalıştırılan yüksek sayıdaki işgücü ve kapladığı alanların farklı amaçla kullanılamaması nedeniyle ekonomik olarak işletilemeyebilirler. Bu sebeple Uşak havalimanı gibi tesislerden uçuş okulları yapılarak ya da mevcut okulların bu tesisleri kullanması sağlanarak, yararlı duruma getirilebilir. Bu amaçla Uşak Üniversitesi’nin planladığı havacılık bölümlerinin açılması şehir ve havalimanı için olumlu bir gelişme olacaktır. Uşak'ın eski bir sanayi şehri olması sayesinde önemli bir sermaye birikiminin olduğunu söylemek mümkündür. İnceleme bölgesindeki girişimcilerin de böyle bir yatırımı yapmaları hem kent ekonomisine hem de bu ulaşım tesisinin gelişmesine katkı sağlayacaktır. Böyle bir fikrin ve girişimin havalimanı yöneticileri tarafindan destekleneceği de mülakatlarda öğrenilmiştir.

Ancak, tesisin kendi amacı olan ulaşım alanında geliştirilmesi, daha önemli görülmektedir. Çünkü tarifeli sefer sayılarının arttırılması ve farklı bölgelere uçuşların gerçekleştirilmesi havayoluna olan talebi de etkileyecektir. Bu haliyle tesis, Devlet Hava Meydanları İşletmesi Müdürlüğü istatistiklerine göre 2011 yılında Türkiye genelinde 1.042.369 olan toplam uçuşun yaklaşık \%0,06'sının yapıldığ 1 ve toplam 117.620 .469 olan yolcu sayısının 15.267 ile \%0,01'inin kullandığı, işlek olmayan bir havalimanıdır. İlçede Ağrı, Adıyaman, Malatya gibi uzak yerleşmelerden göç etmiş önemli bir miktar nüfus yaşamaktadır. Bu potansiyel yeni seferler ile değerlendirilebilir. Yöredeki işadamlarının İstanbul'daki firmalar ile yoğun ticaret yapmaları ve talebe bağlı olarak sefer sayılarının artması halinde havayolları cazip hale gelecektir. Yakın çevresinde Zafer Bölgesel Havalimanı yer almasına rağmen, Uşak Havalimanı bu gibi girişimler ile daha aktif hale getirilebilecektir.

Uşak Garı, Fatih Mahallesi'nde Orhan Dengiz Bulvarı üzerinde yer almaktadır. Garın yolcu taşımacılığında mekân sorunu yoktur. Lojistik birimi için ise bunu söylemek güçtür. Çünkü yükün kaynağını teşkil eden fabrikalar şehrin çeşitli bölgelerinde bulunmaktadır. Bunlardan taşınacak olan yükün kamyonlara yüklenmesi, karayolları ile gara ulaştırılması, yeniden indirilmesi ve vagonlara yüklenmesi firmalara ek maliyet getirmektedir. Bu sebeple özellikle yükün önemli bir miktarının üretildiği Organize Sanayi Bölgelerine çekilecek bir iltisak (tali) hattına gerek duyulmaktadır. Geçmişte bu hattın çekilmesi için girişimlerde bulunulmuş, kamulaştırma gibi maliyetler yüksek tuttuğu için vazgeçilmiştir. $\mathrm{Bu}$ planın dışında Uşak'ta demiryolları ile yük taşımacılığını canlandırabilecek olan bir başka proje de lojistik köy projesidir. TCDD'nin; İstanbul, Kocaeli, Samsun, Eskişehir, Kayseri, Balıkesir, Mersin, Erzurum, Konya, Denizli ve Uşak gibi illerde kurmayı amaçladığı yük taşıma merkezleri bu yerleşmelerin ulaşım işlevi üzerinde önemli bir gelişme sağlayacaktır ${ }^{8}$. Proje kapsamındaki illerden olan Uşak’ta da lojistik köyün tamamlanması durumunda kentin bu işlevinin daha da önem kazanacağı ve bölgesel bir merkez olacağı kuşkusuzdur.

Yapılan mülakatlarda tekstil ve deri sanayiinin daha aktif olduğu dönemlerde demiryolları ile yük ve yolcu taşımacıllğıının daha fazla olduğu saptanmıştır. Bu dönemde, aktarmalı İstanbul hattında da önemli miktarda yolcu taşınmakta olduğu bilgisi verilmiş̧ir.

${ }^{8}$ Lojistik köy projeleri hakkında Bkz. (Karadeniz ve Akpınar, 2011) 
Günümüzde de yolculardan, özellikle İstanbul hattının açılması isteği belirtilmektedir. Ayrıca, Konya hattından gelen yolcular için gece iniş saatlerinin çok geç olması da sıkıntı oluşturmaktadır. Gar idaresinden alınan bilgilere göre şehirden yapılan yük ve yolcu taşımacılığının arttırılabilmesi için hızlı tren hatıının biran önce kurulması gerekmektedir.

Demiryolu ulaşımı sırasında meydana gelen bir diğer olumsuzluk da kazalardır. İhmaller vb. sebeplerle özellikle hemzemin geçitlerde ölümlü kazalar ile karşılaşılabilmektedir. Bu konunun en kısa zamanda çözülmesi için girişimler başlatılmalı belirli yerlere alt veya üst geçitler inşa edilmelidir.

Uşak'ta demiryollarının tarihi değerinin olduğuna biraz önce değinilmişti. Kent içinde kalan gar binasının tarihi yapıları, rekreasyonel amaçlı kullanılabilecek durumdadır. Ayrıca, garda duran tarihi kara trenler de turistik bir çekicilik sunmaktadır. İzmir ili Selçuk ilçesinde yer alan tren müzesine benzer bir müzenin kurulması, kente turistik açıdan katkıda bulanabileceği düşünülebilir (Foto 2).

\section{KAYNAKLAR}

Akbulut, G. (2010). Siyasi Coğrafya Açısından Türkiye'de Demiryolu Ulaşımı. Ankara: Anı Yayınc1lik.

Aliağaoğlu, A. ve Uğur, A. (2012). Şehir Coğrafyası, (2. Basım) Ankara: Nobel Yayıncılık.

Altaş, N.T. (2009). Bozüyük Kent Coğrafyası. Yayınlanmamış Doktora Tezi, Atatürk Üniversitesi Sosyal Bilimler Enstitüsü.

Arıbaş, K. (2008). Bucak (Burdur) 'in Kent Coğrafyası. Konya: Tablet Yayınları No: 72.

Arınç, K. (2006). Türkiye'nin Coğrafi Bölgeleri Kıyı Bölgeleri, I. Cilt. Erzurum: Mega Ofset.

Avcı, S. (2005). Ulaşım Coğrafyası Açısından Türkiye'nin Ulaşım Politikaları ve Coğrafi Sonuçları. Ulusal Coğrafya Kongresi (Prof. Dr. İsmail Yalçınlar Anısına) Bildiri Kitabı 29-30 Eylül, İstanbul.

Bakırcı, M. (2013). Türkiye'nin uluslararası ulaşımında demiryolu sınır kapılarının yeri ve etkinliği, Marmara Coğrafya Dergisi, Say1: 28, 2013:370-407.

Başıüyük, A. (2006). Demiryoluna bağl1 olarak kurulan bir ilçe merkezi: İliç. Doğu Coğrafya Dergisi 15:251-275.

Bekdemir, Ü. (2004). Kurulusu-Gelişmesi ve Fonksiyonel Özellikleri Yönünden Bulancak Kenti. Konya: Çizgi Kitabevi.

Bilgen, N. (1999). Uşak Kent Coğrafyası. Yayımlanmamış Doktora Tezi Marmara Üniversitesi, Sosyal Bilimler Enstitüsü, İstanbul.

Ceylan, M. A. (2010a). Manisa-Uşak demiryolu ulaşımının yerleşme üzerine etkileri (I). Doğu Coğrafya Dergisi. Say1 23: 223-250.

Ceylan, M. A. (2010b). Manisa-Uşak demiryolu ulaşımının yerleşme üzerine etkileri (II). Marmara Coğrafya Dergisi, Sayı 21: 1-26. 
Ulaşım Sistemleri ve Uşak

Çağlıyan, A., Bozkurt Yıldız, A. (2013). Türkiye'de demiryolu güzergâhları jeomorfoloji ilişkisi. Marmara Coğrafya Dergisi, Sayı: 28: 466-486.

Çakmak, B. (2008). Osmanlı Modernleşmesi Bağlamında Bir Batı Anadolu Kazasında Sosyo-Ekonomik Yapı: Uşak (1876-1908) Yayınlanmamış Doktora Tezi, Hacettepe Üniversitesi Sosyal Bilimler Enstitüsü, Ankara.

Çetin, T. (2001) Uşak Şehrinde Nüfus Hareketleri, 21.Yüzyılın Eşiğinde Uşak Sempozyumu, Cilt 2, 25-27 Ekim 2001, Uşak.

Çetin, B. (2007). Burdur Kent Coğrafyası. Yayınlanmamış Doktora Tezi, Atatürk Üniversitesi, Sosyal Bilimler Enstitüsü, Uşak.

Darkot, B., Tuncel, M. (1995). Ege Bölgesi Coğrafyası. 3. Bask1, İstanbul: İstanbul Üniversitesi Yay. No: 2365, Coğrafya Enstitüsü Yay. No: 99..

DHMİ Genel Müdürlüğü (2011). Havacılık Terimleri Sözlüğü, (1.Baskı) Ankara: Devlet Hava Meydanları İşletmesi Genel Müdürlüğü Yayınları-1, APK Daire Başkanlığı, Pulat Basımevi.

DİE (2002). 2000 Genel Nüfüs Sayımı Nüfusun Sosyal ve Ekonomik Nitelikleri, Ankara: DİE.

Doğanay, H. (1983). Erzurum'un Şehirsel Fonksiyonlarl ve Baslıca Plânlama Sorunları, Yayınlanmamış Doçentlik Tezi, Fen-Edeb. Fak. Coğrafya Bölümü, Atatürk Üniversitesi.

Doğanay, H. (2011). Türkiye Ekonomik Coğrafyası, (5. Baskı) Ankara: Pegem Akademi Yayınlar1.

Doğanay, H., Koca, H. (1998). Ulaşımın Yerleşmeye Etkilerine İki Tipik Örnek: Fevzipaşa ve Nurdağı Kasabaları. Türk Coğrafya Dergisi, Sayı: 33: 1-24

Ertin, G. (1993). Karayollarının mekana etkisi üzerine (T.E.M. Otoyolu Kınall-Gebze Kesimi). İstanbul Üniversitesi Deniz Bilimleri ve Coğrafya Enstitüsü Bülten 10: 7387.

Gottman, J. (1976). Şehirsel Merkeziyetin Gelişmesi. (Çev; Nazmiye Özgüç), İstanbul: İstanbul Üniversitesi Yay. No:2087, Coğrafya Enstitüsü Yay. No:80

Gök, Y., (2000). Çevre yollarının Erzurum'un peyzajına etkileri. Türk Coğrafya Dergisi, Sayı 35: $155-172$.

Göney, S. (1977). Şehir Coğrafyası, Yerleşme Coğrafyası, Cilt:1, İstanbul: İstanbul Üniversitesi Edebiyat Fakültesi Yay. No:2274, Coğrafya Enstitüsü. Yay. No:91.

Gürsoy, C. (1974). Türkiye'nin tabii yolları. Türk Coğrafya Dergisi, Sayı: 26: 24-33.

Kadıoğlu, Y. (2007). Trabzon Havalimanı'na coğrafi bir yaklaşım. Marmara Coğrafya Dergisi, Say1 15: 173-190.

Karabulut, Y. (1997). Türkiye'de demiryolu ulaşımı. Türkiye Coğrafyası Dergisi, Sayı 06: 163-187. 
Karadeniz, V. ve Akpınar, E. (2011). Türkiye'de lojistik köy uygulamaları ve yeni bir lojistik köy önerisi, Marmara Coğrafya Dergisi, Sayı: 23: 49-71

Kesici, Ö. (1995). Kilis'in şehir coğrafyası özelliklerine genel bir bakış. Doğu Coğrafya Dergisi, Sayı 01: 246-280.

Koca, H., (1994). Erdemli İlçesinin Beşeri ve İktisadi Coğrafyası. Yayımlanmamış Doktora Tezi, Atatürk Üniversitesi Sosyal Bilimler Enstitüsü, Erzurum.

Kurmuş, O. (1982). Emperyalizmin Türkiye’ye Girişi. Ankara: Savaş Yayınları.

Öz, A. H. (2002). Ulaşım Coğrafyası Açısından Bir Etüt: Türkiye Hava Ulaştırması. Yayımlanmamış Yüksek Lisans Tezi, Atatürk Üniversitesi Sosyal Bilimler Enstitüsü, Erzurum.

Özdeğer, M. (2001). 15.-16. Arşiv Kayıtlarına göre Uşak Kazasının Sosyal ve Ekonomik Tarihi. İstanbul: Filiz Kitabevi.

Özdemir, Ü. (2008). Ulaşım coğrafyası açısından önemli bir güzergah: Karabük-Bartın Karayolu. Doğu Coğrafya Dergisi, Sayı 19: 213-230.

Pamuk, Ş. (1994). Türkiye'deki ilk demiryolu: İzmir-Aydın. Toplumsal Tarih, Sayı: 5, Sayı: 35-37.

Sandal, E. K. (2009). Kahramanmaraş'ta ulaşım problemeleri ve halkın ulaşım sistemine ve problemelerine bakışı. Doğu Coğrafya Dergisi, Sayı 21: 137-159.

Satan, A. (2012). Osmanlı Devri Demiryolu Kronolojisi, (Ed. Engin, V., Doğan, O.) Osmanlı'da Ulaşım Kara Deniz Demiryolu, İstanbul: Çamlıca Basın Yayın.

Sever, R. (2005). Erzurum-Bingöl Karayolu'nda ulaşımı güçleştiren coğrafi etmenler, Doğu Coğrafya Dergisi, Say1 14: 283-311.

Şahin, C. (2000). Trakya otoyolu (Ulaşım coğrafyası açısından bir değerlendirme). Türk Cografya Dergisi, Say1 35: 347-370.

Şahin, İ. F. (2006). Sakaltutan Geçidi'nin (Erzincan) karayolu ulaşımındaki yeri. Doğu Coğrafya Dergisi, Sayı 15: 7-33.

Şahin, İ.F. (2013). Türkiye'de Karayolu Ulaşımı ve Geçitler. Ankara: Pegem Akademi Yayıncilık.

T.C. Uşak Valiliği Çevre ve Şehircilik İl Müdürlüğü, (2012). Uşak İli Çevre Durum Raporu 2011, Uşak: Uşak Çevre ve Şehircilik İl Müdürlüğü.

Taha Orhan Planlama Mühendislik İnşaat Enerji ve Turizm AŞ., (2012). Uşak İli İlave Revizyon Nazım Imar Planı, Araştırma-Değerlendirme Raporu.

Taşlıgil, N. (1996). Türkiye'nin havaalanları, Türk Coğrafya Dergisi, Sayı 31: 259-281.

Taşlıgil, N. (2010). Türkiye'nin Ulaşım Coğrafyası, (2. Baskı), İstanbul: Çantay Yayınevi. 
Ulaşım Sistemleri ve Uşak

Tıraş, M. (2002). Ulaşımın yerleşmeye etkisine bir örnek: Pozantı, Türk Coğrafya Dergisi, Sayı 38: 121-131.

Tutsak, S. (1994). Uşak Kazasında mülki taksimatın gelişimi, Tarih Incelemeleri Dergisi, Say1: IX: 309-325.

Tümer, H. (1971). Uşak Tarihi. İstanbul: Uşak Halk Eğitimine Yardım Derneği Yayınları.

Tümertekin, E. (1987) Ulaşım Coğrafyası (2. Baskı) İstanbul: İstanbul Üniversitesi Yay. No: 2053, Coğrafya Enstitüsü Yay. No: 85.

Tümertekin, E. ve Özgüç, N. (2007) Ekonomik Coğrafya Küreselleşme ve Kalkınma, İstanbul: Çantay Kitabevi.

Uşak Trafik Tescil ve Denetleme Şube Müdürlüğü (2013) 2012 - 2013 Yılları Özet Brifing, Uşak.

Uzuntepe, G. (2000) Osmanlı Imparatorluğu'nda İlk Demiryolu İmir-Aydın-Kasaba (Turgutlu) (1856-1897). Yayınlanmamış Yüksek Lisans Tezi, Anadolu Üniversitesi Sosyal Bilimler Enstitüsü, Eskişehir.

Yalçınlar, İ. (2001) Uşak’ın gelişimindeki hızı arttıracak doğal kaynaklar, 21.Yüzyılın Eşiğinde Uşak Sempozyumu Cilt 2, Uşak.

Yayla, N. (2001). Ulaşım altyapısı ve trafik yönünden Uşak. 21.Yüzyılın Eşiğinde Uşak Sempozyumu Cilt 2, Uşak.

Yazıcı, H. (1995) Şehir coğrafyası açısından bir inceleme: Bayburt. Türk Coğrafya Dergisi Say1 30: 189-218.

Yıldırım, İ. (2001). Cumhuriyet Döneminde Demiryolları (1923-1950). Ankara : Atatürk Araştırma Merkezi.

Yücel, T. (1960). Demiryollarımızın istasyon nüfusuna etkisi, Türk Coğrafya Dergisi, Sayı 20: 143-148.

Yürüdür, E. (2009). Niksar Şehir Coğrafyası. Konya: Çizgi Kitabevi.

İnternet 1. http://www.unece.org/fileadmin/DAM/trans/conventn/ECE-TRANS-SC1384e.pdf (24.02.2014)

İnternet 2. $\quad$ http://tr.wikipedia.org/wiki/Avrupa E-yollar\%C4\%B1\#Bat.C4.B1Do.C4.9Fu_referansl.C4.B1_yollar (24.02.2014)

İnternet 3. http://tr.wikipedia.org/wiki/D 300 (24.02.2014)

İnternet 4. http://tr.wikipedia.org/wiki/D 595 (24.02.2014)

İnternet 5. http://www.dhmi.gov.tr/havaalanlari.aspx?hv=39\#.U4VFo3ZhufM $(26,05,2014)$

http://www.tcdd.gov.tr/ genel/acilistarihleri. htm

http://www.lojistiksozluk.com/iltisak-hatti.html (12.02.2014) 
http://www.dhmi.gov.tr/istatistik.aspx

http://tr.wikipedia.org/wiki/Avrupa_E-yollar\%C4\%B1\#cite_note-1 $(24,02,2014)$

www.kgm.gov.tr (24.02.2014)

http://usaktso.org/joomla/

Trafik Güvenliği Dairesi Başkanlı̆̆ı Ulaşım Etütleri Şubesi Müdürlüğü, Haziran-2013, 2012 Trafik ve Ulaşım Bilgileri, Otoyollar ve Devlet Yollarının Trafik Dilimlerine Göre Yıllık Ortalama Günlük Trafik Değerleri ve Ulaşım Bilgileri www. kgm. gov. tr (24.02.2014)

Trafik Güvenliği Dairesi Başkanlığı Ulaşım Etütleri Şubesi Müdürlüğü, Haziran-2013, 2012 İl Yolları Trafik ve Ulaşım Bilgileri, İl Yollarının Trafik Dilimlerine Göre Yıllık Ortalama Günlük Trafik Değerleri ve Ulaşım Bilgileri www. kgm. gov. tr (24.02.2014)

http://www.kgm.gov.tr/SiteCollectionDocuments/KGMdocuments/Istatistikler/TrafikveUla simBilgileri/12TrafikUlasimBilgileri.pdf $(25,12,2013)$

2011-2012-2013 yılları Uşak Trafik Tescil Büro Amirliği verileri

Uşak Gar Müdürlüğü İstatistikleri

Uşak Garajı İstatistikleri

Uşak Havalimanı İstatistikleri

Uşak Trafik Tescil ve Denetleme Şube Müdürlüğü 
Ulaşım Sistemleri ve Uşak

26 - Doğu Coğrafya Dergisi - 32 